\title{
MYC Oncogene Contributions to Release of Cell Cycle Brakes
}

\author{
Lucía García-Gutiérrez ${ }^{1,2}$, María Dolores Delgado ${ }^{1}$ and Javier León ${ }^{1, *}$ \\ 1 Instituto de Biomedicina y Biotecnología de Cantabria (IBBTEC) CSIC-Universidad de Cantabria and \\ Department of Biología Molecular, Universidad de Cantabria, 39011 Santander, Spain; \\ lucia.garcia@ucd.ie (L.G.-G.); maria.delgado@unican.es (M.D.D.) \\ 2 Systems Biology Ireland, University College Dublin, Belfield, Dublin 4, Ireland \\ * Correspondence: leonj@unican.es; Tel: +34-942-201952
}

Received: 24 February 2019; Accepted: 18 March 2019; Published: 22 March 2019

\begin{abstract}
Promotion of the cell cycle is a major oncogenic mechanism of the oncogene c-MYC (MYC). MYC promotes the cell cycle by not only activating or inducing cyclins and CDKs but also through the downregulation or the impairment of the activity of a set of proteins that act as cell-cycle brakes. This review is focused on the role of MYC as a cell-cycle brake releaser i.e., how MYC stimulates the cell cycle mainly through the functional inactivation of cell cycle inhibitors. MYC antagonizes the activities and/or the expression levels of p15, ARF, p21, and p27. The mechanism involved differs for each protein. p15 (encoded by $C D K N 2 B)$ and p21 (CDKN1A) are repressed by MYC at the transcriptional level. In contrast, MYC activates ARF, which contributes to the apoptosis induced by high MYC levels. At least in some cells types, MYC inhibits the transcription of the p27 gene (CDKN1B) but also enhances p27's degradation through the upregulation of components of ubiquitin ligases complexes. The effect of MYC on cell-cycle brakes also opens the possibility of antitumoral therapies based on synthetic lethal interactions involving MYC and CDKs, for which a series of inhibitors are being developed and tested in clinical trials.
\end{abstract}

Keywords: MYC; cell cycle; CDK inhibitors; p21; p27; p15; ARF

\section{Introduction}

The oncogene c-MYC (referred to herein as MYC) was the first described gene that encoded for an oncogenic transcription factor with the ability to transform cells in culture. MYC is overexpressed by different mechanisms in $60-70 \%$ of human solid and hematopoietic tumors [1-5]. The MYC family of proteins is composed of three members: c-MYC, N-MYC, and L-MYC. The existence of multiple MYC family members with distinct expression patterns reflects different requirements of MYC during development and in the adult animal, which is consistent with the specific way each gene is deregulated in certain cancer types [6].

MYC is a transcription factor of the helix-loop-helix-leucine zipper (HLH-LZ) family that regulates the activation or repression of many target genes [7,8]. Regulation of transcription by MYC depends on the formation of heterodimeric complexes with MAX protein [9]. The MYC-MAX heterodimer is the active form, which binds to specific DNA sequences called E-boxes (canonical sequence CACGTG) in the regulatory regions of target genes. The MYC network (also known as the MAX-MLX network), includes other components of the HLH-LZ family such as the MXDs, MNT, MLX and others, with different functions in gene expression regulation upon binding to E-boxes in the DNA (for recent reviews see $[10,11])$.

The number of MYC-binding sites revealed by genome-wide technologies ranks between 7000 and 15,000 in different models. Indeed, MYC is bound at one or more sites of the regulatory regions of $10-15 \%$ 
of human genes [6-8,12]. In agreement with the large number of MYC target genes, overexpression of MYC deregulates a series of biological functions such as cell-cycle progression, nucleotide biosynthesis, energy metabolism, protein synthesis and ribosome genesis, genomic maintenance, immortalization, and differentiation $[1,7,13-15]$. Such deregulation confers ample competitive advantages to the cell and contributes to the well-stablished role of MYC in a wide variety of cancers.

MYC protein contains several domains that play important roles in MYC functions, as well as many residues susceptible of being modified, modulating MYC's activity and stability [6]. MYC contains an unstructured N-terminal region, which includes two conserved regions known as MYC boxes (MB) (Figure 1). MBI and MBII are located within the transcriptional transactivation domain (TAD), essential for MYC transcriptional and cell-transforming activity. The MBII is crucial for the recruitment of MYC transactivation co-activators such as TRRAP, GCN5, TIP48, TIP49, TIP60, CBP/p300, as well as SKP2 [16-18]. The central region of MYC contains the MBIII, which has been shown to be important for transcriptional repression $[19,20]$ and MBIV, needed for MYC transcriptional activity and MYC induced apoptosis [21]. The C-terminal region of MYC includes the basic, helix-loop-helix, and leucine zipper domains (b-HLH-LZ). Through the basic domain, MYC protein recognizes specific sequences and binds the DNA, while the HLH-LZ domain mediates the dimerization with its major partner MAX $[9,22,23]$.

Activation or repression of MYC-regulated genes is mediated by its interaction with a variety of partner proteins, many of them involved in chromatin structure regulation (recently reviewed in $[17,24]$ ). The mechanism for MYC-mediated transactivation depends on the recruitment of complexes containing histone acetyltransferases (HATs) [7,8] (Figure 1a). TRRAP (Transformation-Transactivation domain Associated Protein) was originally isolated as a cofactor of MYC and recruited to most of the MYC target genes upon mitogen stimulation $[25,26]$. Two different TRRAP containing complexes possess GCN5 HAT activity. TRRAP-containing TIP60 complex consists of the TIP60 HAT, the ATPase/helicase motif containing cofactors TIP48 and TIP49 and the SWI/SNF related protein p400 ATPase. Both GCN5 and TIP60 acetylate histones at MYC target genes. Furthermore, CBP/p300 interacts with MYC mediating its acetylation, increasing MYC stability and stimulating MYC-transcriptional activation [17]. MYC is present at the promoter of nearly all active genes acting as an amplifier of the transcription already going on at those genes $[27,28]$ although there is some selectivity on the genes regulated by MYC $[29,30]$. Different studies support the idea of MYC as a transcription amplifier because of its role regulating global transcriptional pause release [31]. The mechanism is not well known but the activating interaction of MYC with P-TEFb (positive transcription elongation factor b) likely plays an important role in it [32] (Figure 1a).

Apart from transcriptional activation of gene expression, MYC also represses a great number of genes, many of them involved in processes such as the inhibition of cell-cycle progression and cell adhesion $[33,34]$. MYC represses transcription by interacting with other transcription factors and co-repressor complexes at the core promoter region of genes. So far, MYC has been reported to exert its repression activity by interacting mainly with SP1 and/or MIZ-1 (Figure 1b). These two transcription factors normally activate transcription. However, interaction with MYC switches them into transcriptional repressors mainly by displacing SP1 and MIZ-1 co-activators. For example, MIZ-1 recruitment of p300 can be antagonized by MYC [35,36]. Further, MYC represses transcription through SP1 by recruiting histone deacetylases (HDACs) [37]. SP1-SMAD complex has been found to be inactivated by MYC resulting in gene repression [38]. MYC also interacts with SIN3 [19] and with HDAC3 [20]. In this way, MYC recruits HDACs to the core promoter of several genes, resulting in transcriptional repression. The MYC-MIZ-1 complex can recruit the DNA methyltransferase DMNT3A to promoters, repressing transcription. This might be an efficient mechanism to repress CPG island promoters [39]. At least two of the genes known to be repressed by MYC through these mechanisms encode proteins involved in cell-cycle regulation: CDKN1A (p21 $\left.{ }^{\mathrm{CIP} 1}\right)[40,41], C D K N 2 B$ $\left(\mathrm{p} 15^{\mathrm{INK} 4 \mathrm{~B}}\right)[35,38,42]$. 
a

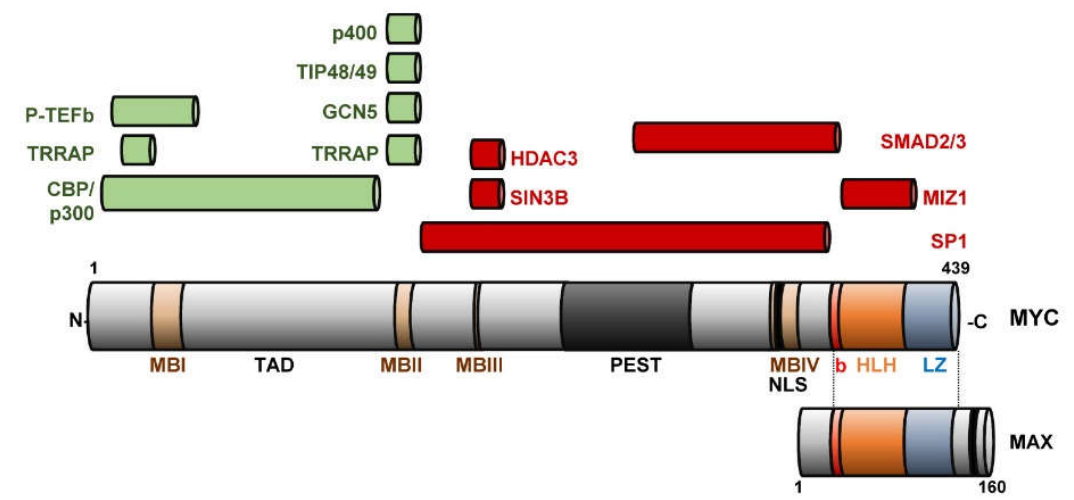

b
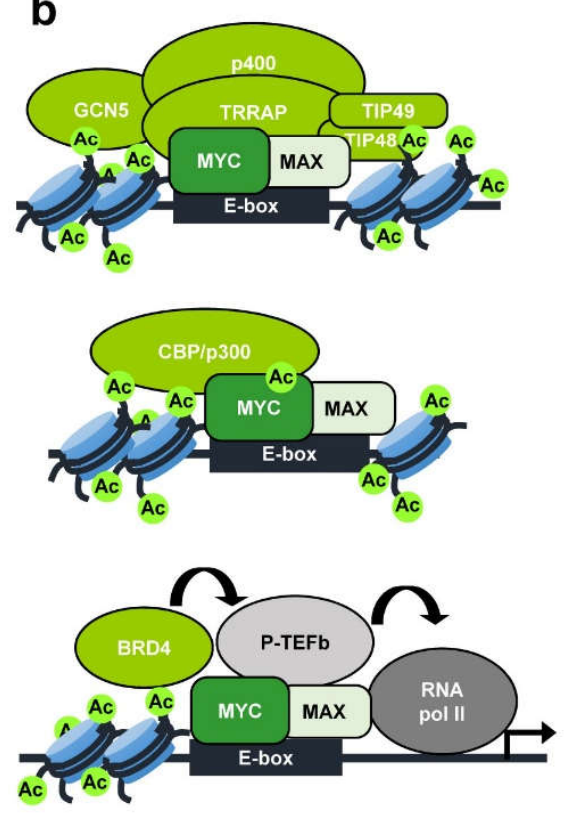

c
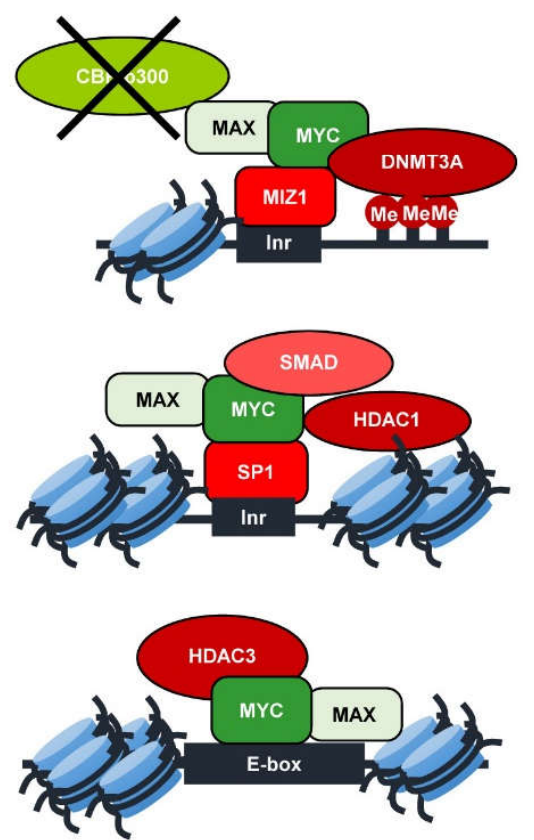

Figure 1. Oncogene c-MYC (MYC) structure and interaction complexes. (a) MYC structural domains are represented. MB, MYC boxes I-IV; TAD, transactivation domain; PEST, PEST sequence; NLS, Nuclear Location Signal. b, basic; HLH, Helix-Loop-Helix; LZ, Leucine Zipper. Through these domains, MYC interacts with different cofactors involved in transcriptional activation (in green) or repression (in red). MYC-MAX interaction is also indicated. (b) Transcriptional activation through MYC-associated complexes. Upper: MYC-MAX heterodimers bind E-box sequences and interact with co-activators such as TRRAP, GCN5 and others. These complexes mediate histone acetylation to transactivate MYC target genes. Middle: CBP/p300 also mediates MYC acetylation and increased stability. Bottom: $\mathrm{BRD} 4$ is a reader of acetylated histones and promotes the activity of $\mathrm{P}-\mathrm{TEFb}$ complex, composed of CyclinT1 and CDK9. MYC interacts with P-TEFb, which phosphorylates the C-terminal domain of RNA polymerase II to trigger elongation. (c) Transcriptional repression through MYC-associated complexes. Upper: MYC interacts with MIZ-1, displacing coactivators with HAT activity such as $\mathrm{CBP} / \mathrm{p} 300$. The MYC/MIZ-1 complex binds to Initiator element (Inr) sequences and recruits the DNA methyltransferase DNMT3A to repress transcription. Middle: SP1-SMAD complex is repressed by MYC. Recruitment of HDAC1 contribute to histone deacetylation nearby Inr sequences. Bottom: MYC also recruits HDAC3 to E-box sequences, reducing histone acetylation.

We will review here the role of MYC as cell-cycle brake releaser i.e., how MYC stimulates cell cycle mainly through the repression of cell-cycle inhibitors (Figure 2). Cell-cycle progression is regulated by serine/threonine protein kinases composed by a catalytic subunit or CDK (cyclin-dependent protein kinase), and a regulatory subunit, the cyclin $[43,44]$. CDK1, 2, 4, and 6 and A, B, E, and D-type cyclins constitute the major regulators of the mammalian cell cycle. D-type cyclins (D1, D2, and 
D3) preferentially bind and activate CDK4 and CDK6 at early $\mathrm{G}_{1}$-phase of the cell cycle, leading to the phosphorylation of the retinoblastoma protein $(\mathrm{RB})$ and the release of the E2F transcription factors [45,46]. Cyclin E1/2-CDK2 complexes in the late $\mathrm{G}_{1}$-phase further phosphorylate RB, allowing the expression of E2F target genes required for the transition to S-phase [47]. Later, CDK2 complexes with Cyclin A2. Cyclin A is required for DNA replication and is expressed through $S$ and $G_{2}$ phases. M-phase transition is regulated by CDK1 activated by B-type cyclins (B1 and B2) [43,48]. CDK inhibitory proteins (CKIs) accomplish an additional level of regulation of the cell cycle. CKIs are divided into two families (Figure 2). The INK4 family (consisting of p16 $6^{\mathrm{INK} 4 \mathrm{~A}}, \mathrm{p} 15^{\mathrm{INK} 4 \mathrm{~B}}, \mathrm{p} 18^{\mathrm{INK} 4 \mathrm{C}}$, and $\mathrm{p} 19^{\mathrm{INK} 4 \mathrm{D}}$ ) binds and inhibits CDK4 and CDK6 kinases, impairing their association with D-type cyclins. The CIP/KIP family (consisting of $\mathrm{p} 21^{\mathrm{CIP} 1}$, $\mathrm{p} 27^{\mathrm{KIP} 1}$, and $\mathrm{p} 57^{\mathrm{KIP} 2}$ ) inhibits progression at every cell-cycle phase upon binding to several already formed Cyclin-CDK complexes [49]. CDK inhibitors are involved in the regulation of a variety of biological processes beyond cell-cycle regulation [50] and some of them play important roles in cancer [51].

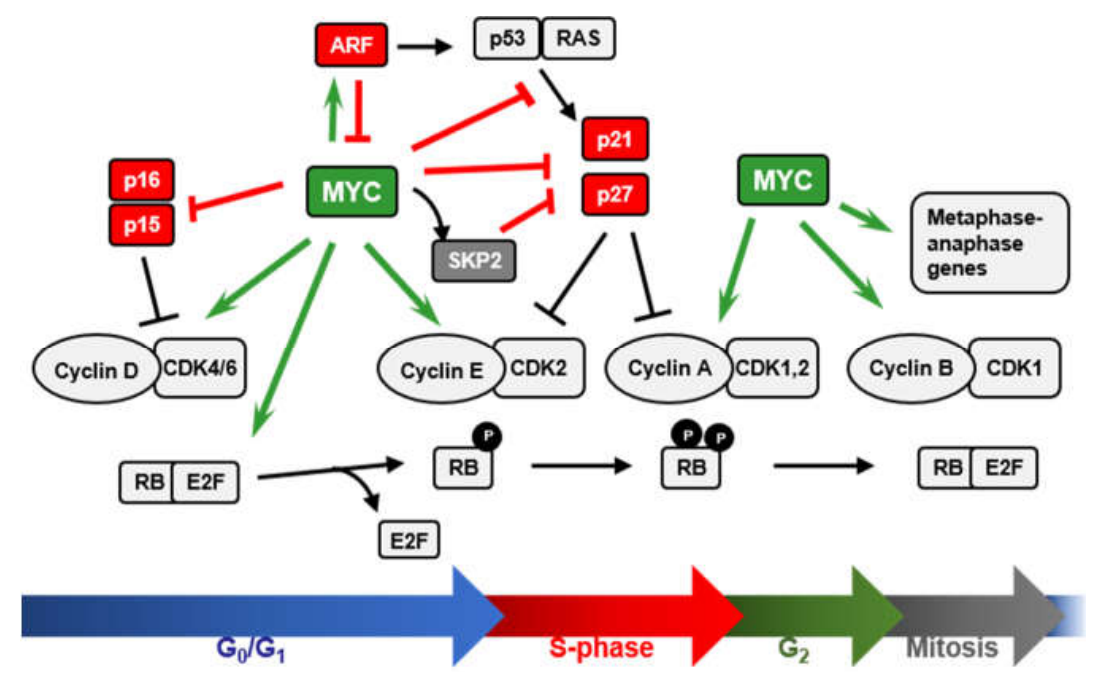

Figure 2. Impact of MYC on cell-cycle regulation. MYC stimulates cell-cycle progression and the cellular proliferation through the regulation of genes related to cell-cycle control. MYC induces positive cell-cycle regulators such as several cyclins, CDKs and E2F transcription factors (green arrows). Cyclin-CDK complexes phosphorylate RB, releasing E2Fs from the inhibitory interaction with RB, and allowing the expression of E2F target genes and the progression through the cell-cycle phases. MYC also represses genes encoding cell-cycle inhibitors such as p15, p21, or p27 (red bars), by different mechanisms. The regulatory mechanisms by which MYC antagonizes the activity of cell-cycle inhibitors are detailed in the text.

MYC stimulates cell-cycle progression through the regulation of many genes related to cell-cycle control (recently reviewed in [13]) (Figure 2). MYC induces critical positive cell-cycle regulators such as cyclins (D-type cyclins, E-type cyclins, cyclin A and cyclin B1), CDKs (CDK1, 2, 4, 6), and E2F transcription factors (E2F1, 2, 3) (reviewed in [13]). Moreover, MYC antagonizes the activity of cell-cycle inhibitors such as p15, p21, and p27 by different mechanisms. These activities of MYC will be discussed below.

\section{MYC and the INK4A/ARF/INK4B Locus}

The INK4A / ARF / INK4B gene locus is located on chromosome 9p21 in humans encoding three related proteins: $\mathrm{p} 15^{\mathrm{INK} 4 \mathrm{~B}}$ ( $\mathrm{p} 15$ herein after), $\mathrm{p} 14^{\mathrm{ARF}}$ in humans or $\mathrm{p} 19^{\mathrm{ARF}}$ in mice (ARF herein after) and $\mathrm{p} 16^{\mathrm{INK} 4 \mathrm{~A}}$ (p16 herein after). p15 and p16 are characterized for their direct interaction with CDK4 and CDK6, blocking the formation of cyclin D-CDK4/ 6 complexes and provoking arrested proliferation through preventing phosphorylation of RB and S-phase entry [52]. On the other hand, ARF protein is unrelated with the INK4 family of CDK inhibitors but it shares the exons 2 and 3 with p16 ${ }^{\text {INK4A }}$ gene, 
while the first exon of each gene is totally different. They are transcribed from an alternative reading frame (i.e., ARF) within the same locus and thus, their amino acid sequences lack any similarity. ARF induces cell-cycle arrest in $G_{1}$ and $G_{2}$ phases [53] and/or apoptosis through the regulation of the ARF/MDM2/p53 apoptotic pathway mainly, although induction of p53-independent apoptosis has also been reported to be mediated by ARF [54,55]. Albeit activation of the p53 apoptotic pathway is commonly mediated by DNA damage or cellular stress responses, ARF acts as an unusual tumor suppressor, being activated by oncogenic signals such as MYC [56] among others (reviewed in [57]). This response is considered as a security measure to avoid aberrant and uncontrolled proliferation due to sustained growth signaling. In fact, the expression of the INK4A/ARF/INK4B locus is lost in a wide range of human tumors (reviewed in [58]). Disruption of the exon 2 of INK4A makes mice more prone to tumor development, an alteration that affects both p16 and ARF. However, specific deletion of the ARF exon 1 in mice lead to the same phenotype while harboring intact p16, confirming ARF as a tumor suppressor playing a key role in protecting cells from aberrant proliferation [59]. In agreement, immortalization of primary mouse embryonic fibroblasts (MEFs) implies normally loss of either ARF or p53 $[60,61]$ and MYC can immortalize MEFs $[62,63]$ through a process that is normally accompanied by either ARF or p53 loss of function [56]. Here we will review the ARF-regulation by MYC and vice-versa, as ARF controls MYC's activity to prevent abnormal proliferation and oncogenic transformation.

\subsection{MYC and $p 15^{I N K 4 B}$ Regulation}

The cell-cycle inhibitor $\mathrm{p} 15$ arrests proliferation in $\mathrm{G}_{1}$ phase by specifically inhibiting cyclin D-CDK4/ 6 complexes [64]. Moreover, high levels of p15 redistribute p27 from cyclin D-CDK4/6 complexes to cyclin E-CDK2 complexes, leading to arrested proliferation [65]. Treatment of lung epithelial cells with TGF $\beta$ lead to a rapid downregulation of MYC levels, while p15 was highly induced. However, exogenous MYC expression resulted in the inhibition of TGF $\beta$-mediated p15 induction [66]. In fact, MYC inhibits the activation of a reporter gene under the control of the proximal region of p15 promoter. This region contained the TGF $\beta$ responsive element (TGF $\beta-R E$ ) and the transcriptional initiator site (Inr) [66]. The repression of p15 by MYC occurs through either mechanisms that involve or not the Inr element. The Inr element consists of a weak consensus sequence located at the transcription start site (TSS) of different promoters through which MYC is known to exert part of its repression activity (reviewed in $[67,68]$ ). Different proteins have been described to cooperate with MYC in the binding to the Inr element, such as YY1, TFII-I and MIZ-1 [69-71]. The zinc-finger protein MIZ-1 recognizes and binds the Inr element of its target genes promoting their activation, such as INK4B upon TGF $\beta$ treatment. MYC-MAX heterodimers impair INK4B expression by interacting with MIZ-1 at the Inr element of its promoter, preventing p300 recruitment by MIZ-1 [35]. TGF $\beta$ inhibited the interaction of MYC with MIZ-1, leading to INK4B induction by MIZ-1 through its interaction with SMAD proteins [42]. On the other hand, MYC can repress INK4B expression independently of the Inr element. This mechanism involves the interaction of MYC with SP1 and SMAD proteins. MYC binds to activated SMAD, forming a repressor complex together with SP1, leading to the inactivation of INK4B expression upon TGF $\beta$ treatment [38].

\subsection{MYC Regulation of ARF Expression}

Although MYC is always related to enhanced proliferation and cell growth, deregulated MYC expression paradoxically triggers apoptosis upon cellular stress conditions such as serum deprivation [56,72]. This process takes places mainly through the 53-dependent apoptosis pathway [73,74] although it has been reported to also happen in a p53-independent manner [75] in some cell types. Thus, cells overexpressing MYC are subjected to a high selection pressure to proliferate in the absence of growing factors, in which programmed cell death mechanisms need to be abrogated. MYC-induced apoptosis is mainly mediated by the induction of ARF expression at the mRNA level, leading to the inactivation of MDM2 by its sequestration to the nucleolus and thus, stabilization and activation of p53. Activation of p53 results in subsequent induction of p21 and other proteins involved 
in the p53-dependent apoptosis pathway [76]. In fact, p53-null cells showed resistance to MYC-induced apoptosis, while the effect observed in ARF-null cells was less compromised [56]. MYC has been found to induce p53 expression in an ARF-independent manner, although p53-dependent apoptosis was significantly compromised in ARF-null cells [56]. Furthermore, lymphomagenesis induced by MYC in E $\mu-M Y C$ transgenic mice [77], selectively inactivates either ARF or p53 in most tumors, being both genes found mutated with similar frequency [78]. In agreement with previous results obtained in MEFs, E $\mu$-MYC derived pre-B cells showed high rates of apoptosis and increased ARF levels, while p53 levels remained constant when compared to control cells. Thus, high rates of spontaneous cell death in this model correlated with ARF activation [78]. Although in most of the cases, ARF and p16 were inactivated due to mutations within their shared DNA sequences, retained expression of non-altered p16 found in some of these tumors brought to light the importance of ARF but not p16 for B-cell lymphoma development [78]. Thus, loss of ARF attenuates MYC-induced apoptosis in vivo, allowing prevalence of MYC oncogenic activity leading to high rates of tumor formation. In agreement, INK4A/ARF ${ }^{-/-}$-E $\mu$-MYC mice were more prone to develop lymphomas and displayed apoptotic defects despite the presence of wild-type p53, a phenotype similar to the one observed in p53-null lymphomas [79]. Other studies using mouse models with restricted expression of the oncogene MYC to the epidermis and other epithelial tissues $[80,81]$ showed nearly completely abrogated apoptosis in a p53-null background [81] and highly reduced in ARF-null mice [82], consistent with previous studies. Moreover, ARF modulated specifically MYC-mediated apoptosis, while MYC-mediated stimulation of proliferation was not affected in the absence of ARF in the epidermis.

The mechanism of ARF expression induction by MYC remains largely unclear, although it seems to happen through an indirect mechanism involving the regulation of other factors that directly activate ARF expression. MYC induces FoxO transcription factors, which bind to and regulate the INK4A/ARF locus activating ARF expression. Thus, constitutive MYC signaling induces both nuclear FoxO levels and ARF expression [83]. On the other hand, the transcription factor E2F1 directly induces ARF [84], although this pathway does not seem to be conserved in mouse [85]. As MYC is known to directly regulate E2F1 expression, MYC-mediated ARF upregulation through E2F1 regulation has been suggested [86]. On the other hand, MYC has been reported to modulate ARF protein stability by interfering with ARF ubiquitination and degradation. ARF is very unstable in normal cells, while its degradation is inhibited in cancerous cells. The ubiquitin ligase ULF has been reported to ubiquitylate ARF leading to its degradation in vitro and in vivo. Furthermore, MYC can interact with ULF, impeding ARF ubiquitination and thus, increasing its stability [87]. This control of ARF stability is thought to be a mechanism by which the cell senses and distinguishes between normal versus overexpressed MYC. Thus, only upon oncogenic MYC levels, ULF-mediated ARF degradation is inhibited and therefore the apoptotic response is activated [88]. Consistently, physiological levels of MYC did not activate ARF promoter [89].

\subsection{ARF-Mediated Regulation of MYC Activity}

Apart from the p53-dependent ARF induction of apoptosis and arrested proliferation through MDM2 sequestration, ARF has been proposed to have p53- and MDM2-independent functions to suppress cell proliferation [75]. Moreover, ARF has been suggested to interact with targets other than p53 and MDM2 to inhibit proliferation [54]. ARF was found to interact with MYC to relocalize it from the nucleoplasm to the nucleolus and thus, inhibiting MYC-activated transcription and leading to $\mathrm{G}_{1}$ arrest in a p53-independent manner [90]. An ARF mutant lacking the N-terminal domain of the protein failed to interact and colocalize with MYC and thus, was not able to inhibit MYC-activated transcription [90]. In contrast, other studies have shown that upon ectopic MYC expression, ARF is relocalized from the nucleolus to the nucleoplasm and colocalized with it. The same result was obtained upon MYC-ER activation, a chimeric protein consisting of MYC fused to the estrogen receptor and activatable by 4-hydroxy-tamoxifen. [91]. This discrepancy has been attributed most likely to the different systems used for each study and the different ratio levels between ARF and MYC in 
each model. Thus, MYC/ARF localization is bidirectional. MYC interacts with ARF through two different domains, one through the TAD situated at the N-terminal, and the other one through the HLH-LZ domain, located at the C-terminus of MYC [17]. Although the C-terminal domain had only a minimal effect over ARF interaction when deleted, depletion of the TAD completely abrogated MYC-ARF interaction [91]. Notably, ARF antagonizes the SKP2-mediated ubiquitylation of the MYC TAD [92]. MYC-p14ARF interaction has also been demonstrated and takes place through the MBII of MYC. This interaction leads to inhibition of MYC-induced transcription and nucleolar localization of MYC [93]. Chromatin immunoprecipitation assays showed that ARF was recruited to active MYC target genes, forming complexes with MYC-MAX heterodimers, impairing MYC-transactivating activity without affecting MYC-transrepressing activity [57]. Thus, this mechanism of ARF blocking MYC transactivation of genes impairs MYC-mediated hyperproliferation probably by ARF-mediated interference of TAD interaction with MYC-coactivators [91]. Many target genes which are repressed by MYC are involved in anti-apoptotic functions. The fact that ARF impairs MYC transactivation activity but that it does not interfere with MYC repression mechanisms would favor the pro-apoptotic response within the cells upon deregulated MYC activity [94-96].

\section{MYC and p21 Regulation}

The CIP/KIP cell-cycle inhibitor p21 Cip1/Waf1 (p21), encoded by the CDKN1A gene, plays key roles in controlling cellular processes such as proliferation, senescence, cell differentiation and apoptosis (reviewed in $[97,98]$ ). Similar to its relative p27, p21 interacts with cyclin-CDK complexes inhibiting cell-cycle progression $[99,100]$ in response to different stimuli. p21 is a transcriptional target of p53, essential for $p 53$ induced cell-cycle arrest in $G_{1}$ and $G_{2}$ phases upon DNA damage $[101,102]$. One of the first evidences in which MYC was found to have an opposite effect over p21-mediated cell-cycle arrest was reported by Perez-Roger and colleagues, when they showed that MYC promoted p21 sequestration through induction of D-type cyclins [103]. While a strong RAF signal was found to promote cell-cycle arrest through p21 induction in NIH 3T3-derived cells [104], MYC-ER activation was able to counteract this effect by an increase in cyclin D2-p21 binding that was proportional to the increase in cyclin D2 expression mediated by MYC [103]. However, MYC-ER activation did not lead to increased cyclin D1 expression in this system, in agreement with the lack of increased binding of p21 to cyclin D1 upon these conditions [103]. One of the major mechanisms by which MYC induces S-phase entry relies on MYC's ability to activate cyclin E-CDK2 complexes [13]. Thus, apart from the induction of Cyclin E expression (among others), MYC-mediated release of cyclin E-CDK2 inhibition though induction of cyclin D2 and further sequestration of p21 in cyclin D-CDK4/6 complexes [13] constitutes a remarkably important process in MYC's role as pro-proliferative agent.

\subsection{MYC-Mediated p21 Repression by Direct Recruitment to Its Core Promoter Region}

The better characterized and most studied mechanism by which MYC is known to counteract the antiproliferative activity of p21 occurs at the transcriptional level (Figure 3). In fact, p21 has been reported to be one of the major targets of MYC repression [105]. This regulation of p21 by MYC is a clear example of MYC as transcriptional repressor, an idea that is becoming widely accepted and studied and that seems to account for at least half of MYC's activity as transcriptional regulator, as revealed in transcriptomic analysis upon MYC enforced expression.

Several mechanisms have been reported as per which MYC is able to repress transcription (reviewed in $[34,36])$, however further research needs to be performed to better understand how this process takes place. Histone deacetylase recruitment to promoter regions is a well-known mechanism of transcriptional repression. Indeed, trichostatine A (a histone deacetylase inhibitor) treatment has been shown to induce p21 expression [106]. Different studies have found that MYC-mediated CDKN1A transcriptional repression occurs in a HDAC-independent manner [40,107]. Besides, cells stably expressing the MYC-ER construct repressed the expression of CDKN1A upon MYC-ER activation, even in the absence of de novo protein synthesis. The inhibition of de novo protein synthesis diminishes 
the possibility that an intermediate protein could be responsible for this effect, meaning that MYC directly triggers p21 repression [40]. The CDKN1A promoter contains three non-canonical E-box sequences, two of them close to the transcription start site (TSS) ( -5 to $+1 \mathrm{bp}$ and -20 to $-15 \mathrm{bp}$ ) and another one around $150 \mathrm{bp}$ upstream the TSS ( -162 to $-157 \mathrm{bp}$ ) (Figure 3a). Whether MYC repression activity relies on MYC's ability to recognize and interact with the DNA through E-boxes is not yet determined. In the case of $C D K N 1 A$, direct MYC DNA binding has not been reported so far, thus its activity on CDKN1A promoter is E-box independent. Different studies reported that a short sequence within the transcription start site (from around -150 to $+16 \mathrm{bp}$ ) is enough for MYC to repress CDKN1A promoter's activity $[40,41,107]$. This promoter region contains several responsive elements as shown in Figure 3. MYC is recruited to the promoter DNA sequence by interacting with other transcription factors involved the regulation of CDKN1A expression, being SP1/SP3 and MIZ-1 the main ones described so far $[40,41,108]$. TGF $\beta$ treatment of murine and human keratinocytes leads to MYC downregulation followed by p21 induction and cell-cycle arrest [107]. Luciferase assays using different $C D K N 1 A$ promoter fragments revealed that the TGF $\beta$ responsive element is not needed for MYC-mediated p21 repression. A luciferase construct containing from -62 to $+16 \mathrm{bp}$ of the CDKN1A promoter, was enough for MYC to mediate promoter repression and thus, MYC exerts its regulation independently of the rest of elements that act upstream that sequence, such as p53 or C/EBP [40]. Within the vicinity of the CDKN1A transcription start site that is enough for MYC to repress p21 expression, there are multiple SP1 binding sites and a potential Inr sequence. The initiator binding protein (TFII-I) induces gene transcription from the Inr of certain TSS and MYC is known to interact with the TFII-I impeding its activity in other models. However, that was not the case for CDKN1A, as depletion of the Inr sequence ( +7 to $+16 \mathrm{bp}$ from the TSS) did not affect MYC repression of CDKN1A promoter in colorectal adenocarcinoma cells. Instead, MYC was found to interact with SP1 and SP3 transcription factors which play important roles in the induction of p21 expression [108]. The central part of the MYC protein, from amino acids 143 to 352, is essential for MYC to interact with the zinc finger domain of SP1 and enough to counteract SP1 induction of CDKN1A expression in CaCo cells [40].

The mechanism by which MYC represses $C D K N 1 A$ promoter activity seems to be cell-type dependent. MYC also represses $C D K N 1 A$ expression by interacting with the initiator-binding transcription factor MIZ-1. During hematopoietic differentiation, MIZ-1 levels increase and trigger CDKN1A expression, while ectopic MYC expression repressed basal or TPA-induced CDKN1A levels [41]. The MYC responsive region of CDKN1A promoter in this model was found to be between -49 and $+16 \mathrm{bp}$ from the transcription start site, a sequence already reported in other studies, as mentioned above. Nevertheless, opposite to previous reports [40], the Inr sequence was essential for MIZ-1-dependent recruitment of MYC to impair CDKN1A expression in other studies [41]. Again, MYC binding to the DNA was not necessary as the basic domain of MYC protein is not needed for CDKN1A repression. Instead, MYC was recruited to the DNA by interacting through its HLH domain with MIZ-1 $[41,109]$. The MYC ${ }^{\text {V394 }}$ mutant (HLH mutated domain), unable to interact efficiently with MIZ-1 although still capable of interacting with MAX, allowed p21 expression and cell differentiation, bringing to light that MYC-MIZ-1 interaction is essential for CDKN1A repression [41].

More recently, MYC has been shown to form a ternary complex with MIZ-1 and GFI-1 able to bind the CDKN1A core promoter resulting in p21 repression [110] (Figure 3b). GFI-1 is a nuclear transcriptional repressor found to have important roles in hematopoietic cells [111-113] as well as in other tissues [114-116] and it has been reported to cooperate with MYC in lymphomagenesis [117,118]. GFI-1 regulates CDKN1A expression by recruitment of HDAC1 and G9a $[119,120]$. Nevertheless, although GFI-1 has two binding sites located 1.4 and $2.8 \mathrm{~Kb}$ upstream CDKN1A TSS, GFI-1 repression of CDKN1A expression happened through a mechanism that is independent of its DNA binding ability [119,120]. Instead, and according to this study [110], recruitment of both MYC and GFI-1 is dependent on MIZ-1 leading to the formation of a ternary complex that binds CDKN1A core promoter. Knocking down MIZ-1 expression leads to a significant decrease in MYC and GFI-1 occupancy at the CDKN1A promoter region. Indeed, MIZ-1 binds GFI-1 through its C-terminal 1-12 ZFs, while the 
regions flaking the ZFs are required for MYC interaction [109]. Besides, TGF $\beta$ not only would induce p21 through reduction of MYC expression [107], but also it reduces the levels of GFI-1, an effect that may contribute to the disruption of the MIZ-1/MYC/GFI-1 complex at the CDKN1A promoter region allowing p21 expression [110].

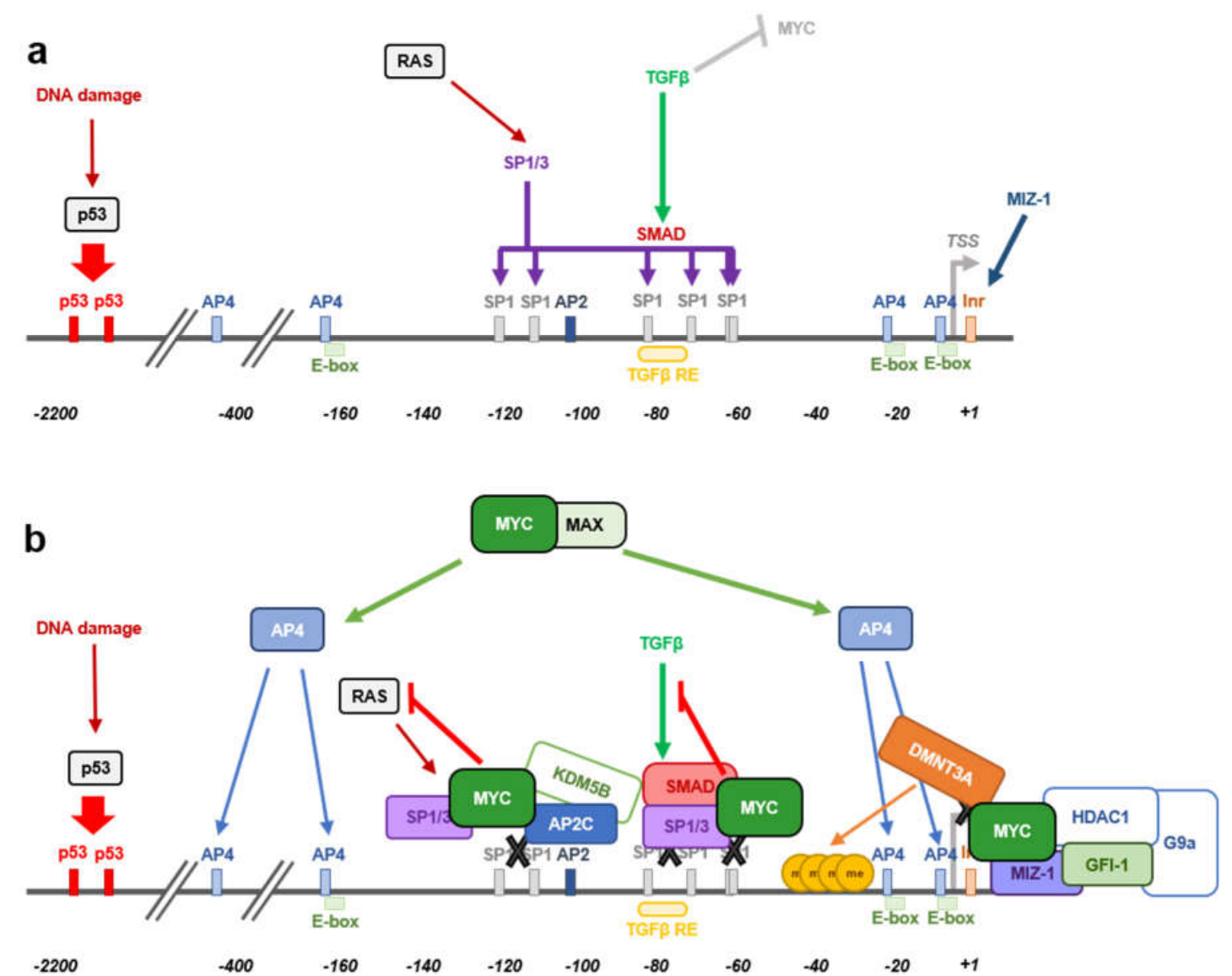

Figure 3. Transcriptional repression of CDKN1A (p21) by MYC. (a) Scheme of CDKN1A promoter region showing the localization of responsive elements for different transcription factors. In response to DNA damage, p53 induces CDKN1A transcriptional activation upon binding to the indicated sites. RAS mediates p21 induction through the SP1 sites. TGF $\beta$ also induces p21 and cell-cycle arrest upon binding to TGF $\beta$-responsive element in the promoter. MIZ-1 transcription factor binds to the initiator sequence (Inr) to trigger p21 expression. TSS, transcription start site. (b) MYC represses CDKN1A at different levels. MYC is recruited to the promoter by interacting with SP1 and MIZ-1. At the Inr, MYC interacts with MIZ-1 and DNMT3A or forms a ternary complex with MIZ-1 and GFI-1, recruiting HDAC1 and G9a to repress p21. MYC interaction with SP1 counteracts SP1 induction of p21 by RAS or TGF $\beta$ signal. AP4 is a direct MYC target gene which mediates $C D K N 1 A$ repression upon binding to the indicated sites in the promoter. MYC interacts with AP2C and recruits KDM5B through the AP-2 binding site promoting histone demethylation and CDKN1A repression.

Another ternary complex involving MYC and MIZ-1 together with DMNT3A has been described to inhibit $C D K N 1 A$ expression by inducing $C \mathrm{pG}$ methylation within the $C D K N 1 A$ core promoter (Figure 3b) [39]. Combination of ectopic expression of MYC and DMNT3A has been found to highly repress $C D K N 1 A$, while downregulation of DMNT3A restores its expression [39]. MYC recruits DMNT3A to the core promoter of CDKN1A through MIZ-1, forming a ternary complex in which MYC is essential for bringing together MIZ-1 and DMNT3A [39]. Moreover, inhibition of DNA methyltransferase activity through 5-aza-cytidine abolished the MYC-mediated repression of CDKN1A, proving that DNA methyltransferase activity is needed for MYC to accomplish p21 downregulation [39]. On the other hand, histone demethylation activity has been reported to cooperate 
with MYC in CDKN1A repression. MYC forms a complex with TFAP2C (AP2C herein after) and the histone demethylase KDM5B capable to bind and repress the core promoter of CDKN1A through the AP2-binding site located -111 to $-103 \mathrm{bp}$ from the TSS (Figure 3b). Although AP2C and MYC are capable of repressing p21 expression alone, recruitment of KDM5B is dependent on both transcription factors and required for an optimal CDKN1A repression [121]. Thus, MYC would not only block the expression of p21 by interfering with factors that upregulate its expression, it will also actively modulate CDKN1A transcription by recruitment of DNA methyltransferase and histone demethylase activities to its core promoter.

\subsection{MYC-Dependent Switch from Cell-Cycle Arrest to Apoptosis by Inhibiting p53-Dependent Activation of} p21 Expression

Activation of the p53 pathway upon DNA damage can lead to two different outcomes, either cell-cycle arrest, mediated by the p53-direct induction of CDKN1A transcription, or apoptosis, mediated by 553 induction of PUMA and PIG3, among other target genes. MYC plays a very important role in the choice of this response. By interacting with MIZ-1, MYC is recruited to the proximal promoter region of CDKN1A leading to the inhibition of p53 mediated p21 expression in HTC116 cells upon MYC overexpression [122]. MYC did not affect p53 binding to CDKN1A promoter neither that of PUMA or PIG3, but specifically inhibited p21 expression promoting PUMA-mediated apoptosis instead of p21-dependent cell-cycle arrest [123]. Similar results were obtained in K562 cells, in which p53 activation lead to apoptosis or cell-cycle arrest while MYC overexpression significantly impaired apoptosis and p21 induction by p53, without affecting BAX expression [124].

\subsection{MYC-Mediated Inhibition of RAS-Induced CDKN1A Expression}

Cooperation between RAS and MYC in cellular transformation was the first example of oncogenes cooperation and has been widely studied since then [62]. Apart from its pro-proliferative activity, RAS is known to induce cell-cycle arrest and senescence in different models of primary cells $[125,126]$ and chronic myeloid leukemia (CML) cells [127]. This mechanism of RAS-induced cell-cycle arrest involves the induction of cell-cycle inhibitors such as p16 (leading to RB inactivation), ARF and p53 that subsequently activates p21 expression and cell-cycle arrest. The mechanism through which RAS mediates p21 induction was first described to happen mainly through SP1 sites 2 and 4 in Cos7 cells [128]. Few years later, RAS induction of p21 expression was reported to be dependent on RAF in a model of CML (K562 cells). In this study, the SP1 sites 2 and 5 are the ones that account for the main RAS transactivation activity on CDKN1A promoter, although sites 3 and 4 also contributed to it [108]. Like other models already described, MYC was able to impair RAS-induced CDKN1A expression by binding to SP1 and inhibiting SP1-mediated CDKN1A expression regardless of the SP1 site analyzed [108] (Figure 3b). HLH and MB2 domains were needed for MYC to exert its repression on CDNK1A promoter upon RAS activation, in a process independent of MIZ-1 [108]. Thus, MYC exerts a major role in controlling the CDKN1A promoter in a silent state in CML, promoting cell-cycle progression and contributing to tumorigenesis. However, in agreement with the fact that cell context is essential to determine the outcome of a biological process, depending on the signal that induces the expression of p21, MYC will mediate its repressive activity over CDKN1A promoter through one mechanism or another. In fact, MYC seems to adapt its regulation ability according to the factor which mainly regulates p21 expression depending on the cellular context. These multiple mechanisms of MYC-induced p21 repression bring to light the importance of p21 regulation for MYC to promote cell proliferation and transformation.

\subsection{MYC-Indirect Repression of CDKN1A Expression}

Apart from the direct regulation of p21 transcription by MYC through its recruitment to the core promoter of the CDKN1A gene, mediated by protein-protein interactions with other CDKN1A regulators, MYC can induce transcription factors and miRNAs that are directly involved in the 
regulation CDKN1A expressions. TFAP4 (AP4 herein after) is a direct MYC target gene that belongs to the bHLH-LZ family of transcription factors. Its basic DNA-binding domain is essential to mediate CDKN1A repression through recognition of the E-boxes located at the core promoter of this gene $[129,130]$. AP4 only forms homodimers, so that it is very unlikely that AP4 exerts its repression by interacting with other transcription factors. Instead, it may compete for the occupancy of the E-boxes with other bHLH-LZ transcription factors known to induce CDKN1A expression [131]. AP4 is known to repress gene expression by recruitment of HDAC (HDAC1 and HDAC3) to core promoters [132,133]. Nevertheless, inhibition of HDAC activity is not enough to abolish AP4-mediated CDKN1A repression [134], in agreement with the HDAC-independent MYC-mediated p21 repression already addressed $[40,107]$. Other studies have described other potential mechanism for AP4-mediated p21 repression in which AP4 would impair TBP interaction with the TATA-box within the TSS, preventing the assembly of the RNA polymerase II complex [132,135].

Finally, MYC has been shown to regulate p21 expression at the post-transcriptional level, by modulation of miRNA expression (Figure 4). p21 is a major target of the miR-17 family of miRNAs and it has also been reported that silencing of p21 due to aberrant regulation of miRNA-17 contributes to tumorigenesis [136-138]. Moreover, the miR-17 family members correlate with MYC expression [139-141] and indeed, $m i R-17-5 p, m i R-20 a$, and $m i R-106 a$, all of them belonging to the miR-17 family of miRNAs are induced by MYC and downregulate p21 expression [142]. Thus, miRNA regulation by MYC indirectly regulates p21 expression contributing to the promotion of cell proliferation by MYC.

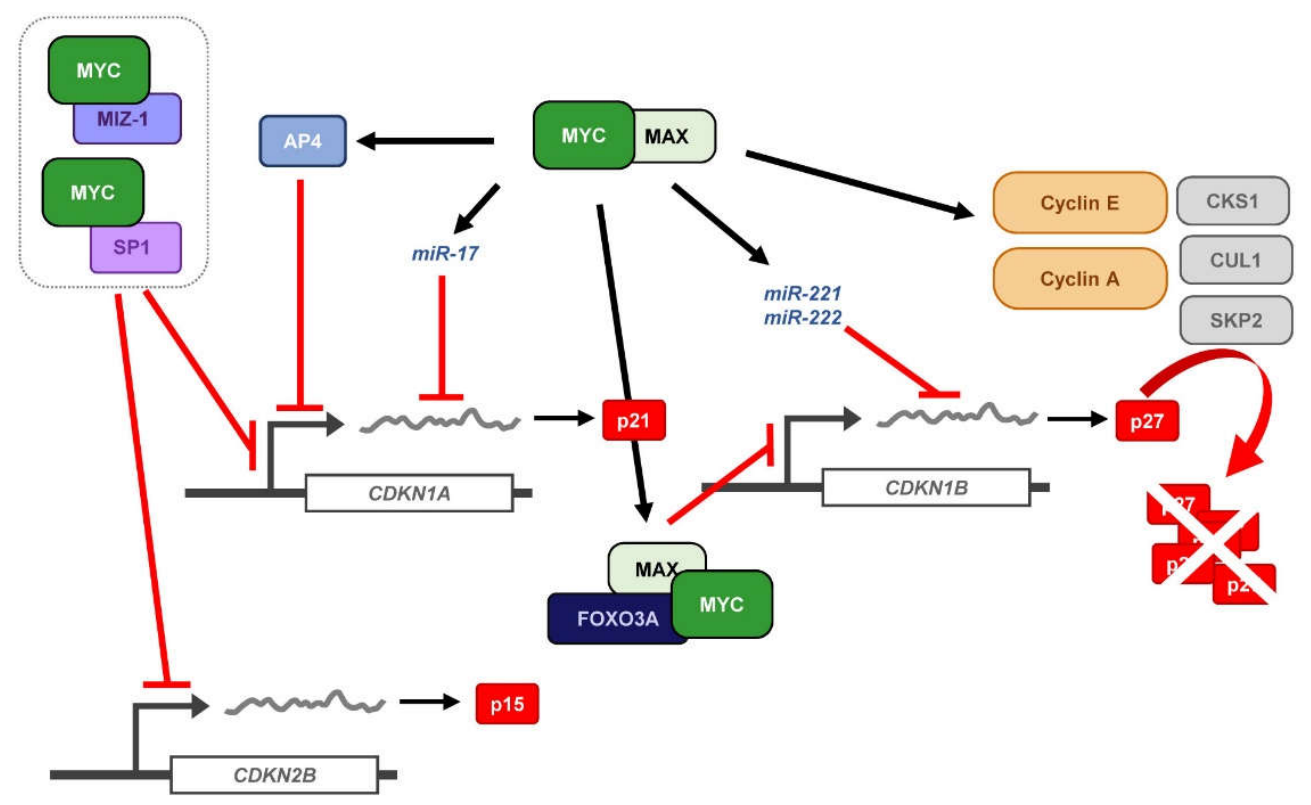

Figure 4. Mechanisms for MYC-mediated antagonism of CKIs p15, p21, and p27. MYC directly represses $C D K N 2 B$ and $C D K N 1 A$ promoters by interacting with MIZ-1 or SP1. MYC also induces the transcriptional repressor AP4 or the microRNA mir-17 to repress p21 expression. Although MYC-mediated repression of CDKN1B has been reported, the major mechanisms for the abrogation of p27 are related to the sequestering of p27 by cyclin-CDK complexes and to p27 degradation. See text for details.

\section{MYC and p27 Regulation}

The cell-cycle inhibitor $\mathrm{p} 27^{\mathrm{Kip} 1}$ (p27), encoded by the CDKN1B gene, is known to induce proliferation arrest in $\mathrm{G}_{1}$ by blocking the kinase activity of cyclin-CDK complexes, being cyclin E-CDK2 inhibition which exerts its main role in cell-cycle control. Besides, p27 behaves as a transcriptional regulator involved in a variety of cellular functions and in cancer (recently reviewed in [143]). Since MYC is a well-known potent inductor of the transition from $G_{1}$ to S-phase, the antagonistic effect 
found between MYC and p27 in the control of cell-cycle progression has been a matter of study for many years. This is consistent with the fact that $M Y C^{-/-}$cells showed increased levels of p27 and inhibition of cyclin-CDK activity, together with reduced proliferation rates [144]. Moreover, the opposite correlation between high levels of MYC and low levels of p27 has been found in many human tumors and it is considered as poor prognosis of the disease $[145,146]$. There are several mechanisms through which MYC counteracts p27 activity, thus enabling the $\mathrm{G}_{1}-\mathrm{S}$ transition: (i) repression of p27 at the transcriptional level; (ii) induction of $m i R-221$ and $m i R-222$ that down-regulate p27 expression; (iii) induction of D-type cyclins and CDK4 and CDK6 that sequester p27 from cyclin E-CDK2 complexes; (iv) induction of CCNE expression directly or through E2F, leading to activation of cyclin E-CDK2 complexes that antagonize p27 function; $\mathrm{v}$ ) induction of different components of the SCF ${ }^{\mathrm{SKP} 2}$ ubiquitin ligase complex (i.e., CKS1, CUL1 and SKP2) that targets $\mathrm{p} 27$ for proteasomal degradation (Figure 4). Mechanisms (i) and (ii) lead to CDKN1B regulation at the mRNA level, either due to promoter repression or post-transcriptional regulation. However, these two mechanisms of repression account for a minor percentage of MYC-mediated p27 regulation. The last three mechanisms contribute to p27 downregulation in a much higher extent, mostly involving p27 protein sequestration and degradation by MYC [147]. These mechanisms are discussed below.

\subsection{Repression of CDKN1B Expression}

One of the mechanisms that accounts for the inhibition of $\mathrm{p} 27$ by MYC involves MYC-mediated transcriptional repression of the $C D K N 1 B$ core promoter, as already described for its related CDKN1A gene. CDKN1B mRNA expression levels inversely correlate with MYC expression in immune cells and other models. B cell receptor (BCR) engagement in immature B cells (upon anti-IgM treatment) lead to MYC downregulation, followed by p27 expression and induction of apoptosis [148], an effect that is reproduced upon siRNA-mediated MYC downregulation [149] and blocked by MYC [148-150]. Thus, there is an inverse correlation between $M Y C$ and $C D K N 1 B$ mRNA expression levels in this model upon IgM treatment. Luciferase assays showed that the CDKN1B promoter region containing from -2002 to $+154 \mathrm{bp}$ responded to anti-IgM treatment leading to an increase in CDKN1B promoter activity [151]. The CDKN1B promoter contains an Inr element at the TSS which, as already described for other MYC-repressed target genes, has been found to be crucial for CDKN1B downregulation and MYC has been reported to interact with it in different models [151]. Indeed, CDKN1B upregulation upon BCR engagement is abrogated by ectopic MYC expression [151]. MYC interaction with the Inr element relies on its MBII and accordingly, a MYC ${ }^{\mathrm{P} 115 \mathrm{~L}}$ mutant, in which the Phe at the position 155 is replaced by a Leu within the region of MYC needed for its transcriptional suppression function, enhances its repressor activity [151], consistently with other known MYC-repression mechanisms [67,152,153]. Later studies showed that MYC represses $C D K N 1 B$ promoter by direct interaction and inhibition of Foxo3a, a transcription factor known to upregulate CDKN1B expression [154]. In fact, immature B cells subjected to anti-IgM treatment showed an increase in Foxo3a expression [155], which can be abrogated by MYC expression [154]. Opposite to what was found for CDKN1A, MYC interacts with the CDKN1B Inr element through MAX, blocking CDKN1B expression [151].

\subsection{MYC-Induced Repression of 227 Through miRNA Up-Regulation}

Regulation of $C D K N 1 B$ at the post-transcriptional level by miRNAs has been recurrently reported during the last years. Indeed, aberrant up-regulation of miRNA clusters that regulate p27 expression have been linked with cancer development, progression and invasion [156-158], bringing to light the importance of p27 regulation at this level. Screening of the miRNAs involved in the regulation of p27 revealed that the miR-221 family of miRNAs directly regulates the expression of p27 by targeting its $3^{\prime}$ UTR sequence (Figure 4). miR-221 and miR-222, both belonging to this miRNA family, were predicted and verified to downregulate p27 expression in cell culture models [159]. MYC plays a key role in the regulation of non-coding RNAs and thus, modulates the expression of their target genes, a mechanism that has become recently more evident. MYC-regulation of miRNA expression has been linked mainly 
with miRNAs targeting mRNAs involved in cell-cycle regulation. In fact, MYC directly regulates the miR-221 family of miRNAs, which have been found to target p27 (and p57) [160]. Besides, miR-221 and $m i R-222$ are consistently overexpressed in liver tumors, showing an opposite correlation with low levels of p27 due to its aberrant pros-transcriptional regulation. Furthermore, miR-221 (but not $m i R-222)$ has been reported to enhance tumorigenesis not only in vitro, but also in vivo [161].

\subsection{Sequestration of 27 by Cyclin D-CDK4/6 Complexes}

Inhibition of the cell cycle by p27 is controlled, in a great extent, by its recruitment to cyclin D-CDK4/6 complexes. The shift of p27 from cyclin E/CDK2 to cyclin D-CDK4/6 complexes relieves cyclin E-CDK2 from p27-mediated inhibition allowing progression through the cell cycle [162]. Intriguingly, p27 binds constitutively to cyclin D-CDK4/6 complexes. Although considered a CDK inhibitor, p27 has been found associated with both, active and inactive cyclin D-CDK4/6 complexes, depending on the cell proliferation state and on the phosphorylated status of p27 [163,164]. In arrested cells, the unphosphorylated p27 impairs the activation of cyclin D-CDK4/6 complexes by blocking CDK-ATP binding pocket. However, upon mitogenic stimuli, p27 gets phosphorylated at Tyr74, Tyr88, and/or Tyr89, leading to a conformational change that releases the blockade of the ATP binding site and the CDK is further activated by the CAK [164]. Moreover, p27 (as well as p21) is known to stabilize these complexes, as p27 depletion leads to more unstable D-type cyclins and less cyclin D-CDK4/6 complexes. MYC induces the expression of D-type cyclins and CDK4 and CDK6 [13,103], thus leading to the formation of cyclin D-CDK4/ 6 complexes able to sequester p27 from cyclin E-CDK2. Activation of MYC in mouse cells containing the MYC-ER chimera, promoted the interaction of p27 with D-type cyclins in an extent that proportionally correlated with the levels of cyclin D induced by MYC and with the activation of cyclin E-CDK2 complexes [103]. Although it has been reported that MYC directly induces cyclins D1 and D2, there has been some controversy concerning cyclin D1 regulation. Different studies reported opposite effects in the regulation of cyclin D1 by MYC, depending on cell types and models used [103,165-168]. On the other hand, cyclin D2 is well known to be induced by MYC as recurrently reported [103,168-170]. Moreover, CDK4 is also a bona fide MYC target gene [171] which is activated by MYC, presumably through the E-boxes located along its promoter region. Indeed, MYC has been reported to induce CDK4 at the transcriptional level in human and rodent cells and it has been found to activate the CDK4 promoter in reporter assays [171]. Finally, CDK6 is induced by MYC at the mRNA level, although this induction does not correlate with CDK6 protein levels [172,173]. D-type cyclins and CDK4 and 6 are repressed by different miRNAs (as many other genes involved in cell-cycle progression) such as the let-7 family of miRNAs, $m i R-34 a, m i R-15 a / 61$, and $m i R-26 a$. MYC has been reported to induce the expression of D-type cyclins and CDK4/ 6 by repressing these miRNAs. Altogether, MYC induces the formation of cyclin D-CDK4/6 complexes promoting the switch of p27 from cyclin E-CDK2 to cyclin D-CDK4/6 complexes, thus inducing the G1-S phase transition as reviewed in [13].

\subsection{Induction of p27 Degradation Through the MYC/CDK2/SKP2 Axis}

The most important regulation of p27 levels and thus, p27 activity, takes place in the nucleus and relies on p27 protein stability. Upon mitogenic stimuli, p27 levels within the cell need to be reduced to allow cyclin-CDK activation and cell-cycle progression. The most efficient way for the cell to overcome p27 inhibition is mediated by its degradation via proteasome. Proteasomal degradation of p27 is mainly mediated by the SCF ${ }^{\mathrm{SK} P 2}$ ubiquitin ligase complex [174-176] (Figure 5) which, as most of the SCF complexes, relies on a specific phosphorylation state of its target protein to be able to recognize and ubiquitylate it (reviewed in $[177,178]$ ). In the case of p27, phosphorylation at its Thr187 is essential for SCF ${ }^{\mathrm{SKP} 2}$ recognition [176]. p27 phosphorylation and subsequent degradation is induced by MYC, whereas mutation of the threonine of p27 at the position 187 impaired this effect $[179,180]$. Phosphorylation of the Thr187 of p27 is mainly mediated through cyclin E-CDK2 complexes, although it has been found to be phosphorylated as well by cyclin A-CDK2 and cyclin B-CDK1, although in 
a lesser extent and in vitro [181]. Moreover, cells lacking CDK2 have shown phosphorylation of p27 at the Thr187 residue, suggesting that, in the absence of CDK2, there are other/s kinases able to trigger this phosphorylation [182]. In the absence of CDK2, CDK4, and CDK6, the phosphorylation of p27 at Thr187 can be carried out by CDK1 [183]. In vivo, p27 phosphorylated at the Thr187 is found forming complexes with cyclin E/A-CDK2, but not with D-type cyclin complexes [180]. MYC activation of cyclin E-CDK2 complexes during $\mathrm{G}_{1}$ phase was first described in a Rat1-MYC-ER model [184] while the absence of MYC impaired cyclin E-CDK2 activation in exponentially growing conditions [185]. Moreover, CCNE was later reported to be a direct MYC target gene and that MYC could also induce its expression via E2F1, another MYC target gene needed for the $\mathrm{G}_{1}$ to S-phase transition [186,187]. In turn, some E2F factors (E2F1, 2, 3) can repress MYC whereas E2F7 transactivate MYC [188]. On the other hand, MYC directly represses certain miRNAs that target CCNE, such as miR-34a and miR-26a (reviewed in [13]. Thus, MYC activation of cyclin E-CDK2 complexes would rely mainly in MYC's ability to induce cyclin E expression and form new and active cyclin E-CDK2 complexes. Nevertheless, activation of cyclin-CDK complexes is not only dependent on the regulatory subunit of the kinase (the cyclin), but also on the phosphorylation of certain residue within the CDK (Thr160 in CDK2 and their structurally equivalents in CDK1, CDK4, and CDK6). Phosphorylation of these residues is mediated by the CAK (CDK activating complex) [189-191], which consists of three subunits: cyclin H, CDK7 and MAT1. MYC increases CAK activity by augmenting the translation rates of the mRNA of its three components, leading to higher protein levels [192]. On the other hand, MYC activates CDK7 expression. MYC binds to its promoter sequence in mouse ES cells and CDK7 expression is reduced in MYC null rat cells [144,193], thus, MYC actively participates in the regulation of the CAK, promoting cyclin-CDK complexes activation and, in the case of cyclin E-CDK2 complexes, favoring phosphorylation and subsequent inactivation of p27 [194]. Phosphorylation of p27 by cyclin E-CDK2 led to p27 ubiquitination in vitro, suggesting that phosphorylated p27 was a target for the ubiquitin-proteasome degradation system while a p27 T187A mutant did not show this effect [181,195]. In fact, the F-box protein SKP2, which is part of an E3 ubiquitin ligase of the SCF complex, specifically recognizes p27 phosphorylated at the Thr187, promoting p27 degradation, and it is needed for the transition through quiescent state to S-phase. This process leads to the activation of cyclin A-CDK2 complexes inducing S-phase entry and DNA synthesis (Figure 5). Moreover, the T187A p27 mutant suppresses SKP2-induced cyclin A activation and S-phase entry [176,196,197].

The SCF ${ }^{\text {SKP2 }}$ complex is composed by RBX1, CUL1, SKP1, and the F-box protein SKP2 [177,178]. Cell-free extract assays revealed that SKP2 binds to phosphorylated p27 at the C-terminal domain, while the lack of that phosphorylation totally abolished the interaction. Immunodepletion of CUL1, SKP1, or SKP2 abolished p27 degradation [176]. Unlike any other SCF substrate, p27 ubiquitination requires the accessory protein $\mathrm{CKS1}$, which appears to be necessary to bridge between p27 and SCFSKP2. The N-terminal portion of p27 packs with SKP2, a central Glu ${ }^{185}$ side chain inserts between SKP2 and CKS1 and the C-terminal portion containing the phosphorylated Thr187 binds to CKS1 [198]. Further, cyclin A-CDK2 complexes facilitate the recruitment of p27 to the SCF ${ }^{\mathrm{SKP} 2}$-CKS1 stimulating p27 ubiquitination $[181,199,200]$. Cyclin A interacts with SKP2 while CKS1 does with CDK2 and both interactions are essential, as disruption of any of them abolished p27 ubiquitination [200-202].

MYC induces p27 proteasomal degradation through the upregulation of the SCF ${ }^{\text {SKP2 }}$ complex. This is achieved as several components of this complex have been reported to be MYC-target genes: CUL1, CKS1, and SKP2 [179,203,204]. While CKS1 is indirectly induced by MYC, most likely through other transcription factors regulated by MYC and involved in CKS1 transcriptional regulation [203], CUL1 and SKP2 have been described to be direct-MYC target genes. Activation of MYC-ER by 4-hydroxy-tamoxifen resulted in increased mRNA levels of CUL1 and SKP2, even in the absence of de novo protein synthesis. Both contain canonical E-boxes within their core promote and have been reported to be essential for MYC-transcriptional regulation of these genes [179,204]. Depletion of any of the three (CUL1, CKS1, and SKP2) lead to increased p27 protein levels and arrested proliferation, and MYC was unable to counteract it. Besides, overexpression of CUL1 or CKS1 in null MYC cells, 
which reduced p27 levels within the cells, and siRNA mediated depletion of p27, restored MYC's wild type phenotype leading to normal proliferation rates. Thus, the $\mathrm{SCF}^{\mathrm{SKP} 2}$ complex is essential for MYC's activity as a pro-proliferative transcription factor, by means of reducing p27 levels to allow cell-cycle progression. Altogether, it brings to light that MYC plays a critical role in the regulation of p27 degradation via proteasome through the combination of different regulatory mechanisms.

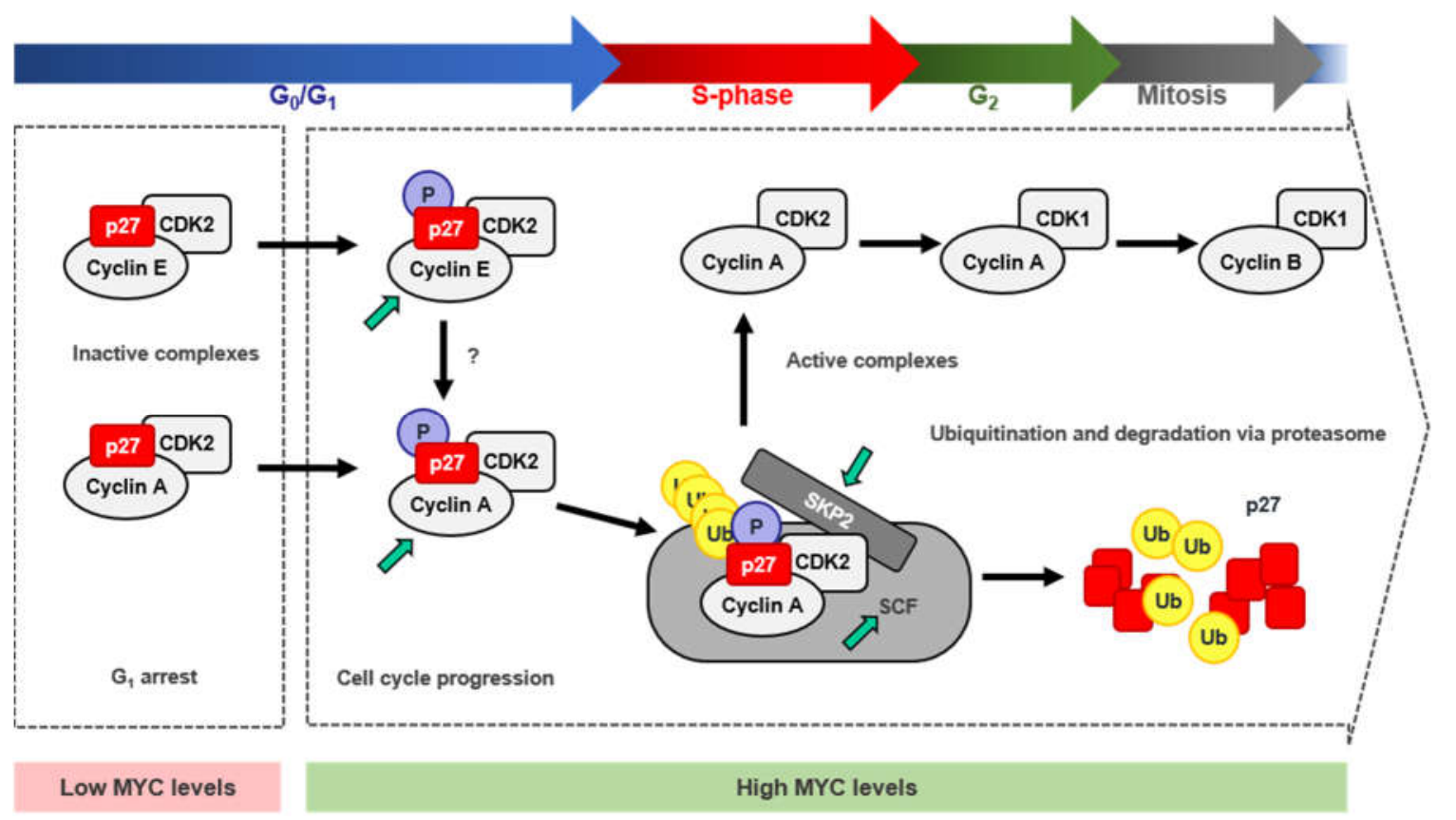

Figure 5. Mechanism for p27 degradation through MYC/CDK2/SKP2 axis. Scheme summarizing the proteasomal degradation of $\mathrm{p} 27$ by the SCF ${ }^{\mathrm{SK}} 2$ complex induced by MYC. During arrested cell proliferation and low MYC levels, unphosphorylated p27 binds and inhibits cyclin E/A-CDK2 complexes. MYC-mediated transition from G1 to S-phase, involves the activation of Cyclin E/A-CDK2 complexes and the phosphorylation of p27 at the Thr187. Phosphorylated p27 is recognized by the SCF ${ }^{\text {SKP2 }}$ ubiquitin-ligase complex when bound to cyclin A-CDK2 complexes and is ubiquitinated and targeted for degradation via proteasome. This process releases the inhibition of Cyclin-CDK complexes by 27 allowing the transition along the different phases of the cell cycle promoting proliferation. Green arrows show MYC target genes.

\section{MYC-Mediated Synthetic Lethality and the Cell Cycle}

MYC would be a good target for therapy. First, MYC deregulation occurs frequently in human cancer. Second, MYC addiction has been shown in several models so that inactivation or depletion of MYC leads to tumor regression [205-207]. The oncogene addiction is defined as the phenomenon by which some tumors exhibit a dependence on a single oncogenic protein or pathway for sustaining growth and proliferation [208].

Third, whole-body inactivation of MYC in mouse models by expression of a dominant negative MYC form (Omomyc, a peptide that interferes with MYC-MAX interaction [209]) only provokes mild side effects. This suggest that pharmacological inhibition of MYC could likely be implemented without major side effects [210,211]. However, to date no anti-MYC drugs have reached the clinical use. Like other transcription factors, MYC has the reputation of a non-druggable target. Despite that, several approaches have targeted MYC. Inhibitors of bromodomain BRD4 protein (JQ1, OTX15 and derivatives) that repress MYC expression [212,213] (Figure 6a) have been tested in clinical assays in lymphoma, but the drug is not specific for MYC but also represses other genes which transcription is dependent on BRD4 [214].

Several molecules have been described to bind MYC and impair its function. Most of these molecules interrupt the MYC-MAX interaction (Figure 6b), as the peptide Omomyc does [215]. Most 
of these compounds, i.e., 10058-F4 and 10074-G5, were discovered using a two-hybrid system [216]. These inhibitors are specific for MYC and have been broadly used in preclinical studies, but they have not reached the clinical use due to its low potency and to its rapid degradation [217].

A more promising approach is to target MYC as an indirect target via synthetic lethal approaches (Figure 6c). Several putative synthetic lethal genes have been identified $[218,219]$, including CDKs. Indeed, the first synthetic lethal MYC interactor described was CDK2, and most of the synthetic lethal combinations of MYC so far reported involve enzymes that functions in cell cycle. They will be briefly discussed below.

a

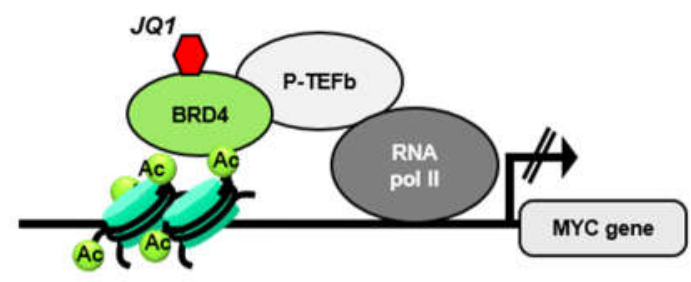

b
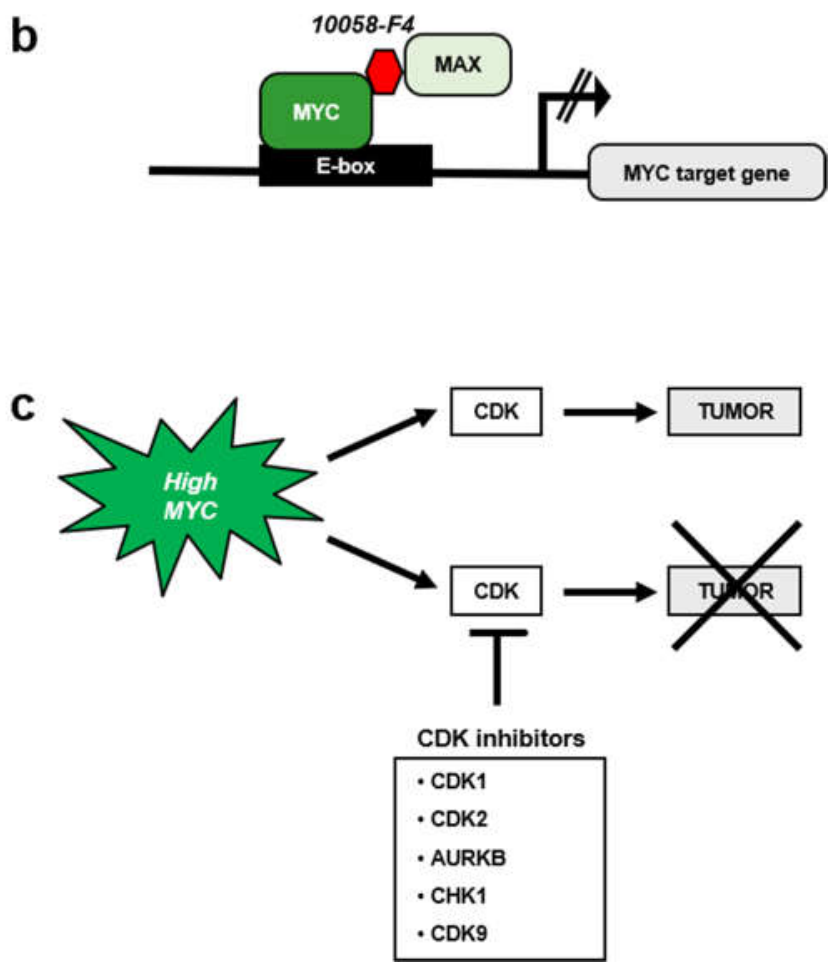

Figure 6. MYC as a therapeutic target in cancer. (a) Mechanism of action of BRD4 inhibitors, such as JQ1, as anti-MYC drugs. (b) MYC inhibition by blocking MYC-MAX interaction with small molecules, such as 10058-F4. (c) Scheme for MYC-mediated synthetic lethality with inhibitors of kinases (CDKs and others) involved in cell-cycle regulation.

\subsection{MYC and CDK1 Inhibitors}

CDK1 is essential for mammalian cell division [220] and is the only CDK required for completion of cell cycle in animal cells [221]. A number of small molecule inhibitors of CDK1 have been developed. Most of them induce an arrest in $G_{2}$ phase, and some are being used in clinical trials [222,223]. Accordingly, a CDK1 inhibitor induces cell death in Burkitt lymphoma and multiple myeloma cell lines depending on MYC levels, and CDK1 inhibition in E $\mu$-Myc mice results in extended survival [224]. Similar observations were made in breast cancer cells [225]. These results suggest that CDK1 inhibition is synthetic lethal on MYC expressing cells. However, purvalanol A is selective but not specific for 
CDK1, and shows some activity against other CDKs [222]. Therefore, the possibility existed that other kinases could contribute to the synthetic lethal effect. However, we have recently shown, using genetic approaches, that CDK1 inhibition is enough for the synthetic lethality with MYC in mouse embryo fibroblasts as it occurs in cells deficient in CDK2, CDK4, and CDK6 [183]. It is worthy to note that CDK1 not only arrests the cell cycle but also plays a role in DNA replication and DNA repair [226]. On the other hand, MYC-induced carcinogenesis is associated to genomic instability, as demonstrated in cell culture and in mice models (reviewed in [227,228]). MYC impairs DNA repair [229] and induces unscheduled DNA replication [230-235]. Therefore, it is conceivable that not only cell-cycle arrest but also the impairment of DNA repair is part of the molecular mechanism of the synthetic lethality between MYC overexpression and CDK1 inhibition.

\subsection{MYC and Aurora Kinase Inhibitors}

Aurora kinases A and B (AURKA and AURKB) are serine/threonine kinases required for mitosis [236]. MYC regulates Aurora Kinase A [237]. Expression of MYC but not that of other oncogenes, made the cells much more sensitive to Aurora kinase inhibitors (e.g., AS703569), being AURKB the central target in this model. Another Aurora kinase inhibitor, VX-680, was demonstrated to selectively kill the cells that overexpress MYC [238]. Indeed, MYC expression levels may provide a biomarker to identify tumors that may respond to aurora $B$ kinase inhibitors. Moreover, the drug inhibited AURKB in vivo using mouse models that develop either B-cell or T-cell lymphomas in response to MYC overexpression, and the lethal response is independent of p53-p21 pathway [239]. This fact is relevant since TP53 is frequently mutated in cancer and usually confers an adverse prognosis.

\subsection{MYC and CHK1 Inhibitors}

One of the effects of MYC overexpression is to induce DNA replicative stress [13], which in turn activates CHK1 (Checkpoint Kinase 1). CHK1 is a serine/threonine kinase that functions as a major component of the DNA damage response. CHK1 regulates cell-cycle checkpoints following genotoxic stress to prevent the entry of cells with damaged DNA into mitosis and coordinates various aspects of DNA repair, and a number of molecules have been described as CHK1 inhibitors [240,241]. In cells from human and murine B-cell lymphomas there is a correlation between MYC and CHK1 levels, although CHK1 seems to be an indirect target of MYC [242]. Silencing of CHK1 with siRNA technology or inactivation with a small molecule results in selective death of MYC-overexpressing cells. These evidences turned CHK1 into an attractive therapeutic target. A CHK1 inhibitor (Chekin), was tested in the $\lambda$-Myc mouse model, where MYC induces lymphomas. In this model CHK1 inhibition was able to induce a significantly slower disease progression [242].

\subsection{MYC and CDK9 Inhibition}

CDK9 is not a kinase involved in cell-cycle progression but in transcription initiation. However, it is worth noting this interaction, given its similarity with cell cycle CDKs. Inhibition or depletion of CDK9 (with shRNAs) in cells and mouse models of hepatocellular carcinoma, results in delay of growth and the extent of its effect correlates with MYC levels, suggesting a synthetic lethal inhibition [243].

\section{Concluding Remarks}

The importance in cancer research of the set of proteins acting as physiological brakes of the cell cycle has been well established. On the other hand, the impairment of CKI activities is a major mechanism for the tumorigenic effects of MYC. Therefore, the deciphering of the molecular clues of the mechanisms leading to MYC-mediated inhibition of p21, p27, and p15 functions or expression is critical for the design of therapeutic approaches of cancers with MYC deregulation. 
Author Contributions: L.G.-G.: preparation of figures, writing the manuscript and preparation of the final version. M.D.D.: preparation of figures and writing the manuscript. J.L.: preparation of figures, writing and overview of the manuscript.

Funding: The work in the laboratory of the authors is funded by grant SAF2017-88026-R from MINECO, Spanish Government, to J.L. and M.D.D., L.G.-G. was recipient of a fellowship from the FPI program from MINECO. The funding was co-sponsored by FEDER program from European Union.

Acknowledgments: We apologize to colleagues whose work has not been cited in the form of their original papers or by unintentional omission.

Conflicts of Interest: The authors declare no conflict of interest.

\section{References}

1. Dang, C.V. MYC on the path to cancer. Cell 2012, 149, 22-35. [CrossRef] [PubMed]

2. Delgado, M.D.; Leon, J. Myc roles in hematopoiesis and leukemia. Genes Cancer 2010, 1, 605-616. [CrossRef]

3. Vita, M.; Henriksson, M. The Myc oncoprotein as a therapeutic target for human cancer. Semin. Cancer Biol. 2006, 16, 318-330. [CrossRef]

4. Kalkat, M.; De Melo, J.; Hickman, K.A.; Lourenco, C.; Redel, C.; Resetca, D.; Tamachi, A.; Tu, W.B.; Penn, L.Z. MYC Deregulation in Primary Human Cancers. Genes 2017, 8, 151. [CrossRef]

5. Schaub, F.X.; Dhankani, V.; Berger, A.C.; Trivedi, M.; Richardson, A.B.; Shaw, R.; Zhao, W.; Zhang, X.; Ventura, A.; Liu, Y.; et al. Pan-cancer Alterations of the MYC Oncogene and Its Proximal Network across the Cancer Genome Atlas. Cell Syst. 2018, 6, 282-300. [CrossRef]

6. Meyer, N.; Penn, L.Z. Reflecting on 25 years with MYC. Nat. Rev. Cancer 2008, 8, 976-990. [CrossRef] [PubMed]

7. Eilers, M.; Eisenman, R.N. Myc's broad reach. Genes Dev. 2008, 22, 2755-2766. [CrossRef] [PubMed]

8. Luscher, B.; Vervoorts, J. Regulation of gene transcription by the oncoprotein MYC. Gene 2012, 494, 145-160. [CrossRef] [PubMed]

9. Blackwood, E.M.; Eisenman, R.N. Max: A helix-loop-helix zipper protein that forms a sequence-specific DNA-binding complex with Myc. Science 1991, 251, 1211-1217. [CrossRef]

10. Carroll, P.A.; Freie, B.W.; Mathsyaraja, H.; Eisenman, R.N. The MYC transcription factor network: Balancing metabolism, proliferation and oncogenesis. Front. Med. 2018, 12, 412-425. [CrossRef]

11. Diolaiti, D.; McFerrin, L.; Carroll, P.A.; Eisenman, R.N. Functional interactions among members of the MAX and MLX transcriptional network during oncogenesis. Biochim. Biophys. Acta 2015, 1849, 484-500. [CrossRef] [PubMed]

12. Van Dang, C.; McMahon, S.B. Emerging Concepts in the Analysis of Transcriptional Targets of the MYC Oncoprotein: Are the Targets Targetable? Genes Cancer 2010, 1, 560-567.

13. Bretones, G.; Delgado, M.D.; Leon, J. Myc and cell cycle control. Biochim. Biophys. Acta 2015, 1849, 506-516. [CrossRef]

14. Leon, J.; Ferrandiz, N.; Acosta, J.C.; Delgado, M.D. Inhibition of cell differentiation: A critical mechanism for MYC-mediated carcinogenesis? Cell Cycle 2009, 8, 1148-1157. [CrossRef]

15. Wolpaw, A.J.; Dang, C.V. MYC-induced metabolic stress and tumorigenesis. Biochim. Biophys. Acta Rev. Cancer 2018, 1870, 43-50. [CrossRef]

16. Conacci-Sorrell, M.; McFerrin, L.; Eisenman, R.N. An overview of MYC and its interactome. Cold Spring Harbor Perspect. Med. 2014, 4, a014357. [CrossRef]

17. Tu, W.B.; Helander, S.; Pilstal, R.; Hickman, K.A.; Lourenco, C.; Jurisica, I.; Raught, B.; Wallner, B.; Sunnerhagen, M.; Penn, L.Z. Myc and its interactors take shape. Biochim. Biophys. Acta 2015, 1849, 469-483. [CrossRef] [PubMed]

18. Adhikary, S.; Eilers, M. Transcriptional regulation and transformation by Myc proteins. Nat. Rev. Mol. Cell Biol. 2005, 6, 635-645. [CrossRef]

19. Garcia-Sanz, P.; Quintanilla, A.; Lafita, M.C.; Moreno-Bueno, G.; Garcia-Gutierrez, L.; Tabor, V.; Varela, I.; Shiio, Y.; Larsson, L.G.; Portillo, F.; et al. Sin3b interacts with Myc and decreases Myc levels. J. Biol. Chem. 2014, 289, 22221-22236. [CrossRef] [PubMed]

20. Kurland, J.F.; Tansey, W.P. Myc-mediated transcriptional repression by recruitment of histone deacetylase. Cancer Res. 2008, 68, 3624-3629. [CrossRef] [PubMed] 
21. Cowling, V.H.; Chandriani, S.; Whitfield, M.L.; Cole, M.D. A conserved Myc protein domain, MBIV, regulates DNA binding, apoptosis, transformation, and G2 arrest. Mol. Cell. Biol. 2006, 26, 4226-4239. [CrossRef] [PubMed]

22. Amati, B.; Dalton, S.; Brooks, M.W.; Littlewood, T.D.; Evan, G.I.; Land, H. Transcriptional activation by the human c-Myc oncoprotein in yeast requires interaction with Max. Nature 1992, 359, 423-426. [CrossRef]

23. Kato, G.J.; Lee, W.M.; Chen, L.L.; Dang, C.V. Max: Functional domains and interaction with c-Myc. Genes Dev. 1992, 6, 81-92. [CrossRef]

24. Poole, C.J.; van Riggelen, J. MYC-Master Regulator of the Cancer Epigenome and Transcriptome. Genes 2017, 8, 142. [CrossRef] [PubMed]

25. McMahon, S.B.; Van Buskirk, H.A.; Dugan, K.A.; Copeland, T.D.; Cole, M.D. The novel ATM-related protein TRRAP is an essential cofactor for the c-Myc and E2F oncoproteins. Cell 1998, 94, 363-374. [CrossRef]

26. Frank, S.R.; Schroeder, M.; Fernandez, P.; Taubert, S.; Amati, B. Binding of c-Myc to chromatin mediates mitogen-induced acetylation of histone $\mathrm{H} 4$ and gene activation. Genes Dev. 2001, 15, 2069-2082. [CrossRef]

27. Nie, Z.; Hu, G.; Wei, G.; Cui, K.; Yamane, A.; Resch, W.; Wang, R.; Green, D.R.; Tessarollo, L.; Casellas, R.; et al. c-Myc is a universal amplifier of expressed genes in lymphocytes and embryonic stem cells. Cell 2012, 151, 68-79. [CrossRef] [PubMed]

28. Lin, C.Y.; Loven, J.; Rahl, P.B.; Paranal, R.M.; Burge, C.B.; Bradner, J.E.; Lee, T.I.; Young, R.A. Transcriptional amplification in tumor cells with elevated c-Myc. Cell 2012, 151, 56-67. [CrossRef]

29. Sabo, A.; Kress, T.R.; Pelizzola, M.; de Pretis, S.; Gorski, M.M.; Tesi, A.; Morelli, M.J.; Bora, P.; Doni, M.; Verrecchia, A.; et al. Selective transcriptional regulation by Myc in cellular growth control and lymphomagenesis. Nature 2014, 511, 488-492. [CrossRef] [PubMed]

30. Wolf, E.; Lin, C.Y.; Eilers, M.; Levens, D.L. Taming of the beast: Shaping Myc-dependent amplification. Trends Cell Biol. 2015, 25, 241-248. [CrossRef]

31. Rahl, P.B.; Lin, C.Y.; Seila, A.C.; Flynn, R.A.; McCuine, S.; Burge, C.B.; Sharp, P.A.; Young, R.A. c-Myc regulates transcriptional pause release. Cell 2010, 141, 432-445. [CrossRef] [PubMed]

32. Rahl, P.B.; Young, R.A. MYC and transcription elongation. Cold Spring Harbor Perspect. Med. 2014, 4, a020990. [CrossRef] [PubMed]

33. Dang, C.V.; O’Donnell, K.A.; Zeller, K.I.; Nguyen, T.; Osthus, R.C.; Li, F. The c-Myc target gene network. Semin. Cancer Biol. 2006, 16, 253-264. [CrossRef] [PubMed]

34. Herkert, B.; Eilers, M. Transcriptional repression: The dark side of myc. Genes Cancer 2010, 1, 580-586. [CrossRef] [PubMed]

35. Staller, P.; Peukert, K.; Kiermaier, A.; Seoane, J.; Lukas, J.; Karsunky, H.; Moroy, T.; Bartek, J.; Massague, J.; Hanel, F.; et al. Repression of $\mathrm{p} 15^{\mathrm{INK} 4 \mathrm{~b}}$ expression by Myc through association with Miz-1. Nat. Cell Biol. 2001, 3, 392-399. [CrossRef] [PubMed]

36. Wiese, K.E.; Walz, S.; von Eyss, B.; Wolf, E.; Athineos, D.; Sansom, O.; Eilers, M. The role of MIZ-1 in MYC-dependent tumorigenesis. Cold Spring Harbor Perspect. Med. 2013, 3, a014290. [CrossRef]

37. Jiang, G.; Espeseth, A.; Hazuda, D.J.; Margolis, D.M. c-Myc and Sp1 contribute to proviral latency by recruiting histone deacetylase 1 to the human immunodeficiency virus type 1 promoter. J. Virol. 2007, 81, 10914-10923. [CrossRef]

38. Feng, X.H.; Liang, Y.Y.; Liang, M.; Zhai, W.; Lin, X. Direct interaction of c-Myc with Smad2 and Smad3 to inhibit TGF- $\beta$-mediated induction of the CDK inhibitor p15 ${ }^{\text {Ink4B }}$. Mol. Cell 2002, 9, 133-143. [CrossRef]

39. Brenner, C.; Deplus, R.; Didelot, C.; Loriot, A.; Vire, E.; De Smet, C.; Gutierrez, A.; Danovi, D.; Bernard, D.; Boon, T.; et al. Myc represses transcription through recruitment of DNA methyltransferase corepressor. EMBO J. 2005, 24, 336-346. [CrossRef] [PubMed]

40. Gartel, A.L.; Ye, X.; Goufman, E.; Shianov, P.; Hay, N.; Najmabadi, F.; Tyner, A.L. Myc represses the p21 (WAF1/CIP1) promoter and interacts with Sp1/Sp3. Proc. Natl. Acad. Sci. USA 2001, 98, 4510-4515. [CrossRef] [PubMed]

41. Wu, S.; Cetinkaya, C.; Munoz-Alonso, M.J.; von der Lehr, N.; Bahram, F.; Beuger, V.; Eilers, M.; Leon, J.; Larsson, L.G. Myc represses differentiation-induced $\mathrm{p} 21^{\mathrm{CIP} 1}$ expression via Miz-1-dependent interaction with the p21 core promoter. Oncogene 2003, 22, 351-360. [CrossRef] [PubMed]

42. Seoane, J.; Pouponnot, C.; Staller, P.; Schader, M.; Eilers, M.; Massague, J. TGF $\beta$ influences Myc, Miz-1 and Smad to control the CDK inhibitor p15 ${ }^{\mathrm{INK} 4 \mathrm{~b}}$. Nat. Cell Biol. 2001, 3, 400-408. [CrossRef] [PubMed] 
43. Malumbres, M.; Barbacid, M. Mammalian cyclin-dependent kinases. Trends Biochem. Sci. 2005, 30, 630-641. [CrossRef] [PubMed]

44. Malumbres, M.; Harlow, E.; Hunt, T.; Hunter, T.; Lahti, J.M.; Manning, G.; Morgan, D.O.; Tsai, L.H.; Wolgemuth, D.J. Cyclin-dependent kinases: A family portrait. Nat. Cell Biol. 2009, 11, 1275-1276. [CrossRef]

45. Sherr, C.J. D-type cyclins. Trends Biochem. Sci. 1995, 20, 187-190. [CrossRef]

46. Dyson, N. The regulation of E2F by pRB-family proteins. Genes Dev. 1998, 12, 2245-2262. [CrossRef] [PubMed]

47. Nevins, J.R. The Rb/E2F pathway and cancer. Hum. Mol. Genet. 2001, 10, 699-703. [CrossRef]

48. Sherr, C.J.; Roberts, J.M. Living with or without cyclins and cyclin-dependent kinases. Genes Dev. 2004, 18, 2699-2711. [CrossRef] [PubMed]

49. Sherr, C.J.; Roberts, J.M. CDK inhibitors: Positive and negative regulators of G1-phase progression. Genes Dev. 1999, 13, 1501-1512. [CrossRef] [PubMed]

50. Besson, A.; Dowdy, S.F.; Roberts, J.M. CDK inhibitors: Cell cycle regulators and beyond. Dev. Cell 2008, 14, 159-169. [CrossRef] [PubMed]

51. Malumbres, M.; Barbacid, M. To cycle or not to cycle: A critical decision in cancer. Nat. Rev. Cancer 2001, 1, 222-231. [CrossRef] [PubMed]

52. Serrano, M.; Hannon, G.J.; Beach, D. A new regulatory motif in cell-cycle control causing specific inhibition of cyclin D/CDK4. Nature 1993, 366, 704-707. [CrossRef] [PubMed]

53. Quelle, D.E.; Zindy, F.; Ashmun, R.A.; Sherr, C.J. Alternative reading frames of the INK4a tumor suppressor gene encode two unrelated proteins capable of inducing cell cycle arrest. Cell 1995, 83, 993-1000. [PubMed]

54. Weber, J.D.; Jeffers, J.R.; Rehg, J.E.; Randle, D.H.; Lozano, G.; Roussel, M.F.; Sherr, C.J.; Zambetti, G.P. p53-independent functions of the p19(ARF) tumor suppressor. Genes Dev. 2000, 14, 2358-2365. [CrossRef]

55. McKeller, R.N.; Fowler, J.L.; Cunningham, J.J.; Warner, N.; Smeyne, R.J.; Zindy, F.; Skapek, S.X. The Arf tumor suppressor gene promotes hyaloid vascular regression during mouse eye development. Proc. Natl. Acad. Sci. USA 2002, 99, 3848-3853. [CrossRef]

56. Zindy, F.; Eischen, C.M.; Randle, D.H.; Kamijo, T.; Cleveland, J.L.; Sherr, C.J.; Roussel, M.F. Myc signaling via the ARF tumor suppressor regulates p53-dependent apoptosis and immortalization. Genes Dev. 1998, 12, 2424-2433. [CrossRef] [PubMed]

57. Gregory, M.A.; Qi, Y.; Hann, S.R. The ARF tumor suppressor: Keeping Myc on a leash. Cell Cycle 2005, 4, 249-252. [CrossRef] [PubMed]

58. Kim, W.Y.; Sharpless, N.E. The regulation of INK4/ARF in cancer and aging. Cell 2006, 127, $265-275$. [CrossRef]

59. Serrano, M.; Lee, H.; Chin, L.; Cordon-Cardo, C.; Beach, D.; DePinho, R.A. Role of the INK4a locus in tumor suppression and cell mortality. Cell 1996, 85, 27-37. [CrossRef]

60. Kamijo, T.; Zindy, F.; Roussel, M.F.; Quelle, D.E.; Downing, J.R.; Ashmun, R.A.; Grosveld, G.; Sherr, C.J. Tumor suppression at the mouse INK $4 a$ locus mediated by the alternative reading frame product p19ARF. Cell 1997, 91, 649-659. [CrossRef]

61. Zindy, F.; Quelle, D.E.; Roussel, M.F.; Sherr, C.J. Expression of the p16 ${ }^{\mathrm{INK} 4 \mathrm{a}}$ tumor suppressor versus other INK4 family members during mouse development and aging. Oncogene 1997, 15, 203-211. [CrossRef]

62. Land, H.; Parada, L.F.; Weinberg, R.A. Tumorigenic conversion of primary embryo fibroblasts requires at least two cooperating oncogenes. Nature 1983, 304, 596-602. [CrossRef]

63. Ruley, H.E. Adenovirus early region $1 \mathrm{~A}$ enables viral and cellular transforming genes to transform primary cells in culture. Nature 1983, 304, 602-606. [CrossRef] [PubMed]

64. Reynisdottir, I.; Polyak, K.; Iavarone, A.; Massague, J. Kip/Cip and Ink4 Cdk inhibitors cooperate to induce cell cycle arrest in response to TGF- $\beta$. Genes Dev. 1995, 9, 1831-1845. [CrossRef] [PubMed]

65. Reynisdottir, I.; Massague, J. The subcellular locations of $\mathrm{p} 15^{(\mathrm{Ink} 4 \mathrm{~b})}$ and $\mathrm{p} 27^{\mathrm{Kip} 1}$ coordinate their inhibitory interactions with cdk4 and cdk2. Genes Dev. 1997, 11, 492-503. [CrossRef]

66. Warner, B.J.; Blain, S.W.; Seoane, J.; Massague, J. Myc downregulation by transforming growth factor $\beta$ required for activation of the $\mathrm{p} 15^{(\mathrm{Ink} 4 \mathrm{~b})} \mathrm{G}_{1}$ arrest pathway. Mol. Cell. Biol. 1999, 19, 5913-5922. [CrossRef] [PubMed]

67. Claassen, G.F.; Hann, S.R. Myc-mediated transformation: The repression connection. Oncogene 1999, 18, 2925-2933. [CrossRef] 
68. Dang, C.V. c-Myc target genes involved in cell growth, apoptosis, and metabolism. Mol. Cell. Biol. 1999, 19, 1-11. [CrossRef]

69. Roy, A.L.; Carruthers, C.; Gutjahr, T.; Roeder, R.G. Direct role for Myc in transcription initiation mediated by interactions with TFII-I. Nature 1993, 365, 359-361. [CrossRef]

70. Schneider, A.; Peukert, K.; Eilers, M.; Hanel, F. Association of Myc with the zinc-finger protein Miz-1 defines a novel pathway for gene regulation by Myc. Curr. Top. Microbiol. Immunol. 1997, 224, 137-146.

71. Shrivastava, A.; Saleque, S.; Kalpana, G.V.; Artandi, S.; Goff, S.P.; Calame, K. Inhibition of transcriptional regulator Yin-Yang-1 by association with c-Myc. Science 1993, 262, 1889-1892. [CrossRef] [PubMed]

72. Evan, G.I.; Wyllie, A.H.; Gilbert, C.S.; Littlewood, T.D.; Land, H.; Brooks, M.; Waters, C.M.; Penn, L.Z.; Hancock, D.C. Induction of apoptosis in fibroblasts by c-Myc protein. Cell 1992, 69, 119-128. [CrossRef]

73. Hermeking, H.; Eick, D. Mediation of c-Myc-induced apoptosis by p53. Science 1994, 265, $2091-2093$. [CrossRef] [PubMed]

74. Wagner, A.J.; Kokontis, J.M.; Hay, N. Myc-mediated apoptosis requires wild-type p53 in a manner independent of cell cycle arrest and the ability of p53 to induce p21waf1/cip1. Genes Dev. 1994, 8, 2817-2830. [CrossRef] [PubMed]

75. Korgaonkar, C.; Zhao, L.; Modestou, M.; Quelle, D.E. ARF function does not require p53 stabilization or Mdm2 relocalization. Mol. Cell. Biol. 2002, 22, 196-206. [CrossRef]

76. Weber, J.D.; Taylor, L.J.; Roussel, M.F.; Sherr, C.J.; Bar-Sagi, D. Nucleolar Arf sequesters Mdm2 and activates p53. Nat. Cell Biol. 1999, 1, 20-26. [CrossRef]

77. Adams, J.M.; Harris, A.W.; Pinkert, C.A.; Corcoran, L.M.; Alexander, W.S.; Cory, S.; Palmiter, R.D.; Brinster, R.L. The c-Myc oncogene driven by immunoglobulin enhancers induces lymphoid malignancy in transgenic mice. Nature 1985, 318, 533-538. [CrossRef] [PubMed]

78. Eischen, C.M.; Weber, J.D.; Roussel, M.F.; Sherr, C.J.; Cleveland, J.L. Disruption of the ARF-Mdm2-p53 tumor suppressor pathway in Myc-induced lymphomagenesis. Genes Dev. 1999, 13, 2658-2669. [CrossRef] [PubMed]

79. Schmitt, C.A.; McCurrach, M.E.; de Stanchina, E.; Wallace-Brodeur, R.R.; Lowe, S.W. INK4a/ARF mutations accelerate lymphomagenesis and promote chemoresistance by disabling p53. Genes Dev. 1999, 13, 2670-2677. [CrossRef] [PubMed]

80. Ramirez, A.; Bravo, A.; Jorcano, J.L.; Vidal, M. Sequences $5^{\prime}$ of the bovine keratin 5 gene direct tissue- and cell-type-specific expression of a lacZ gene in the adult and during development. Differ. Res. Biol. Divers. 1994, 58, 53-64. [CrossRef] [PubMed]

81. Rounbehler, R.J.; Schneider-Broussard, R.; Conti, C.J.; Johnson, D.G. Myc lacks E2F1's ability to suppress skin carcinogenesis. Oncogene 2001, 20, 5341-5349. [CrossRef]

82. Russell, J.L.; Powers, J.T.; Rounbehler, R.J.; Rogers, P.M.; Conti, C.J.; Johnson, D.G. ARF differentially modulates apoptosis induced by E2F1 and Myc. Mol. Cell. Biol. 2002, 22, 1360-1368. [CrossRef] [PubMed]

83. Bouchard, C.; Lee, S.; Paulus-Hock, V.; Loddenkemper, C.; Eilers, M.; Schmitt, C.A. FoxO transcription factors suppress Myc-driven lymphomagenesis via direct activation of Arf. Genes Dev. 2007, 21, 2775-2787. [CrossRef] [PubMed]

84. Bates, S.; Phillips, A.C.; Clark, P.A.; Stott, F.; Peters, G.; Ludwig, R.L.; Vousden, K.H. p14 ${ }^{\text {ARF }}$ links the tumour suppressors RB and p53. Nature 1998, 395, 124-125. [CrossRef] [PubMed]

85. Baudino, T.A.; Maclean, K.H.; Brennan, J.; Parganas, E.; Yang, C.; Aslanian, A.; Lees, J.A.; Sherr, C.J.; Roussel, M.F.; Cleveland, J.L. Myc-mediated proliferation and lymphomagenesis, but not apoptosis, are compromised by E2f1 loss. Mol. Cell 2003, 11, 905-914. [CrossRef]

86. Meyer, N.; Kim, S.S.; Penn, L.Z. The Oscar-worthy role of Myc in apoptosis. Semin. Cancer Biol. 2006, 16, 275-287. [CrossRef] [PubMed]

87. Chen, D.; Shan, J.; Zhu, W.G.; Qin, J.; Gu, W. Transcription-independent ARF regulation in oncogenic stress-mediated p53 responses. Nature 2010, 464, 624-627. [CrossRef]

88. Chen, D.; Kon, N.; Zhong, J.; Zhang, P.; Yu, L.; Gu, W. Differential effects on ARF stability by normal versus oncogenic levels of c-Myc expression. Mol. Cell 2013, 51, 46-56. [CrossRef]

89. Cleveland, J.L.; Sherr, C.J. Antagonism of Myc functions by Arf. Cancer Cell 2004, 6, 309-311. [CrossRef]

90. Datta, A.; Nag, A.; Pan, W.; Hay, N.; Gartel, A.L.; Colamonici, O.; Mori, Y.; Raychaudhuri, P. Myc-ARF (alternate reading frame) interaction inhibits the functions of Myc. J. Biol. Chem. 2004, 279, 36698-36707. [CrossRef] 
91. Qi, Y.; Gregory, M.A.; Li, Z.; Brousal, J.P.; West, K.; Hann, S.R. p19ARF directly and differentially controls the functions of c-Myc independently of p53. Nature 2004, 431, 712-717. [CrossRef]

92. Zhang, Q.; Spears, E.; Boone, D.N.; Li, Z.; Gregory, M.A.; Hann, S.R. Domain-specific c-Myc ubiquitylation controls c-Myc transcriptional and apoptotic activity. Proc. Natl. Acad. Sci. USA 2013, 110, 978-983. [CrossRef]

93. Amente, S.; Gargano, B.; Varrone, F.; Ruggiero, L.; Dominguez-Sola, D.; Lania, L.; Majello, B. p14ARF directly interacts with Myc through the Myc BoxII domain. Cancer Biol. Ther. 2006, 5, 287-291. [CrossRef] [PubMed]

94. Conzen, S.D.; Gottlob, K.; Kandel, E.S.; Khanduri, P.; Wagner, A.J.; O’Leary, M.; Hay, N. Induction of cell cycle progression and acceleration of apoptosis are two separable functions of c-Myc: Transrepression correlates with acceleration of apoptosis. Mol. Cell. Biol. 2000, 20, 6008-6018. [CrossRef] [PubMed]

95. Oster, S.K.; Mao, D.Y.; Kennedy, J.; Penn, L.Z. Functional analysis of the N-terminal domain of the Myc oncoprotein. Oncogene 2003, 22, 1998-2010. [CrossRef] [PubMed]

96. Soucek, L.; Jucker, R.; Panacchia, L.; Ricordy, R.; Tato, F.; Nasi, S. Omomyc, a potential Myc dominant negative, enhances Myc-induced apoptosis. Cancer Res. 2002, 62, 3507-3510.

97. El-Deiry, W.S. p21(WAF1) Mediates Cell-Cycle Inhibition, Relevant to Cancer Suppression and Therapy. Cancer Res. 2016, 76, 5189-5191. [CrossRef] [PubMed]

98. Karimian, A.; Ahmadi, Y.; Yousefi, B. Multiple functions of p21 in cell cycle, apoptosis and transcriptional regulation after DNA damage. DNA Repair 2016, 42, 63-71. [CrossRef] [PubMed]

99. Brugarolas, J.; Moberg, K.; Boyd, S.D.; Taya, Y.; Jacks, T.; Lees, J.A. Inhibition of cyclin-dependent kinase 2 by p21 is necessary for retinoblastoma protein-mediated G1 arrest after gamma-irradiation. Proc. Natl. Acad. Sci. USA 1999, 96, 1002-1007. [CrossRef] [PubMed]

100. Gartel, A.L.; Serfas, M.S.; Tyner, A.L. p21-Negative regulator of the cell cycle. Proc. Soc. Exp. Biol. Med. Soc. Exp. Biol. Med. 1996, 213, 138-149. [CrossRef]

101. Bunz, F.; Dutriaux, A.; Lengauer, C.; Waldman, T.; Zhou, S.; Brown, J.P.; Sedivy, J.M.; Kinzler, K.W.; Vogelstein, B. Requirement for p53 and p21 to sustain G2 arrest after DNA damage. Science 1998, 282, 1497-1501. [CrossRef] [PubMed]

102. Waldman, T.; Kinzler, K.W.; Vogelstein, B. p21 is necessary for the p53-mediated G1 arrest in human cancer cells. Cancer Res. 1995, 55, 5187-5190. [PubMed]

103. Perez-Roger, I.; Kim, S.H.; Griffiths, B.; Sewing, A.; Land, H. Cyclins D1 and D2 mediate Myc-induced proliferation via sequestration of $\mathrm{p} 27^{\mathrm{Kip} 1}$ and $21^{\mathrm{Cip} 1}$. EMBO J. 1999, 18, 5310-5320. [CrossRef] [PubMed]

104. Sewing, A.; Wiseman, B.; Lloyd, A.C.; Land, H. High-intensity Raf signal causes cell cycle arrest mediated by p21Cip1. Mol. Cell. Biol. 1997, 17, 5588-5597. [CrossRef]

105. Coller, H.A.; Grandori, C.; Tamayo, P.; Colbert, T.; Lander, E.S.; Eisenman, R.N.; Golub, T.R. Expression analysis with oligonucleotide microarrays reveals that MYC regulates genes involved in growth, cell cycle, signaling, and adhesion. Proc. Natl. Acad. Sci. USA 2000, 97, 3260-3265. [CrossRef] [PubMed]

106. Sowa, Y.; Orita, T.; Hiranabe-Minamikawa, S.; Nakano, K.; Mizuno, T.; Nomura, H.; Sakai, T. Histone deacetylase inhibitor activates the p21/WAF1/Cip1 gene promoter through the Sp1 sites. Ann. N. Y. Acad. Sci. 1999, 886, 195-199. [CrossRef] [PubMed]

107. Claassen, G.F.; Hann, S.R. A role for transcriptional repression of p21CIP1 by c-Myc in overcoming transforming growth factor $\beta$-induced cell-cycle arrest. Proc. Natl. Acad. Sci. USA 2000, 97, 9498-9503. [CrossRef]

108. Vaque, J.P.; Navascues, J.; Shiio, Y.; Laiho, M.; Ajenjo, N.; Mauleon, I.; Matallanas, D.; Crespo, P.; Leon, J. Myc antagonizes Ras-mediated growth arrest in leukemia cells through the inhibition of the Ras-ERK-p21Cip1 pathway. J. Biol. Chem. 2005, 280, 1112-1122. [CrossRef]

109. Peukert, K.; Staller, P.; Schneider, A.; Carmichael, G.; Hanel, F.; Eilers, M. An alternative pathway for gene regulation by Myc. EMBO J. 1997, 16, 5672-5686. [CrossRef]

110. Liu, Q.; Basu, S.; Qiu, Y.; Tang, F.; Dong, F. A role of Miz-1 in Gfi-1-mediated transcriptional repression of CDKN1A. Oncogene 2010, 29, 2843-2852. [CrossRef]

111. Hock, H.; Hamblen, M.J.; Rooke, H.M.; Traver, D.; Bronson, R.T.; Cameron, S.; Orkin, S.H. Intrinsic requirement for zinc finger transcription factor Gfi-1 in neutrophil differentiation. Immunity 2003, 18, 109-120. [CrossRef] 
112. Karsunky, H.; Zeng, H.; Schmidt, T.; Zevnik, B.; Kluge, R.; Schmid, K.W.; Duhrsen, U.; Moroy, T. Inflammatory reactions and severe neutropenia in mice lacking the transcriptional repressor Gfi1. Nat. Genet. 2002, 30, 295-300. [CrossRef] [PubMed]

113. Zhu, J.; Jankovic, D.; Grinberg, A.; Guo, L.; Paul, W.E. Gfi-1 plays an important role in IL-2-mediated Th2 cell expansion. Proc. Natl. Acad. Sci. USA 2006, 103, 18214-18219. [CrossRef] [PubMed]

114. Kazanjian, A.; Wallis, D.; Au, N.; Nigam, R.; Venken, K.J.; Cagle, P.T.; Dickey, B.F.; Bellen, H.J.; Gilks, C.B.; Grimes, H.L. Growth factor independence-1 is expressed in primary human neuroendocrine lung carcinomas and mediates the differentiation of murine pulmonary neuroendocrine cells. Cancer Res. 2004, 64, 6874-6882. [CrossRef] [PubMed]

115. Shroyer, N.F.; Wallis, D.; Venken, K.J.; Bellen, H.J.; Zoghbi, H.Y. Gfi1 functions downstream of Math1 to control intestinal secretory cell subtype allocation and differentiation. Genes Dev. 2005, 19, 2412-2417. [CrossRef] [PubMed]

116. Wallis, D.; Hamblen, M.; Zhou, Y.; Venken, K.J.; Schumacher, A.; Grimes, H.L.; Zoghbi, H.Y.; Orkin, S.H.; Bellen, H.J. The zinc finger transcription factor Gfi1, implicated in lymphomagenesis, is required for inner ear hair cell differentiation and survival. Development 2003, 130, 221-232. [CrossRef]

117. Schmidt, T.; Karsunky, H.; Gau, E.; Zevnik, B.; Elsasser, H.P.; Moroy, T. Zinc finger protein GFI-1 has low oncogenic potential but cooperates strongly with pim and myc genes in T-cell lymphomagenesis. Oncogene 1998, 17, 2661-2667. [CrossRef]

118. Zornig, M.; Schmidt, T.; Karsunky, H.; Grzeschiczek, A.; Moroy, T. Zinc finger protein GFI-1 cooperates with myc and pim-1 in T-cell lymphomagenesis by reducing the requirements for IL-2. Oncogene 1996, 12, 1789-1801.

119. Duan, Z.; Horwitz, M. Targets of the transcriptional repressor oncoprotein Gfi-1. Proc. Natl. Acad. Sci. USA 2003, 100, 5932-5937. [CrossRef] [PubMed]

120. Duan, Z.; Zarebski, A.; Montoya-Durango, D.; Grimes, H.L.; Horwitz, M. Gfil coordinates epigenetic repression of $\mathrm{p} 21^{\mathrm{Cip} / \mathrm{WAF} 1}$ by recruitment of histone lysine methyltransferase G9a and histone deacetylase 1. Mol. Cell. Biol. 2005, 25, 10338-10351. [CrossRef]

121. Wong, P.P.; Miranda, F.; Chan, K.V.; Berlato, C.; Hurst, H.C.; Scibetta, A.G. Histone demethylase KDM5B collaborates with TFAP2C and Myc to repress the cell cycle inhibitor $p 21^{\text {cip }}$ (CDKN1A). Mol. Cell. Biol. 2012, 32, 1633-1644. [CrossRef]

122. Ferrandiz, N.; Martin-Perez, J.; Blanco, R.; Donertas, D.; Weber, A.; Eilers, M.; Dotto, P.; Delgado, M.D.; Leon, J. HCT116 cells deficient in $\mathrm{p} 21^{\text {Waf1 }}$ are hypersensitive to tyrosine kinase inhibitors and adriamycin through a mechanism unrelated to p21 and dependent on p53. DNA Repair 2009, 8, 390-399. [CrossRef]

123. Seoane, J.; Le, H.V.; Massague, J. Myc suppression of the $\mathrm{p}^{21^{\mathrm{Cip}} 1} \mathrm{Cdk}$ inhibitor influences the outcome of the p53 response to DNA damage. Nature 2002, 419, 729-734. [CrossRef] [PubMed]

124. Ceballos, E.; Delgado, M.D.; Gutierrez, P.; Richard, C.; Muller, D.; Eilers, M.; Ehinger, M.; Gullberg, U.; Leon, J. c-Myc antagonizes the effect of $\mathrm{p} 53$ on apoptosis and p21 ${ }^{\mathrm{WAF} 1}$ transactivation in K562 leukemia cells. Oncogene 2000, 19, 2194-2204. [CrossRef] [PubMed]

125. Lin, A.W.; Barradas, M.; Stone, J.C.; van Aelst, L.; Serrano, M.; Lowe, S.W. Premature senescence involving p53 and p16 is activated in response to constitutive MEK/MAPK mitogenic signaling. Genes Dev. 1998, 12, 3008-3019. [CrossRef] [PubMed]

126. Serrano, M.; Lin, A.W.; McCurrach, M.E.; Beach, D.; Lowe, S.W. Oncogenic ras provokes premature cell senescence associated with accumulation of p53 and p16 ${ }^{\mathrm{INK} 4 \mathrm{a}}$. Cell 1997, 88, 593-602. [CrossRef]

127. Delgado, M.D.; Vaque, J.P.; Arozarena, I.; Lopez-Ilasaca, M.A.; Martinez, C.; Crespo, P.; Leon, J. H-, K- and $\mathrm{N}-$ Ras inhibit myeloid leukemia cell proliferation by a p21 ${ }^{\mathrm{WAF} 1}$-dependent mechanism. Oncogene 2000, 19, 783-790. [CrossRef] [PubMed]

128. Kivinen, L.; Tsubari, M.; Haapajarvi, T.; Datto, M.B.; Wang, X.F.; Laiho, M. Ras induces p21 Cip1/Waf1 ${ }^{\text {cyclin }}$ kinase inhibitor transcriptionally through Sp1-binding sites. Oncogene 1999, 18, 6252-6261. [CrossRef]

129. Mermod, N.; Williams, T.J.; Tjian, R. Enhancer binding factors AP-4 and AP-1 act in concert to activate SV40 late transcription in vitro. Nature 1988, 332, 557-561. [CrossRef]

130. Jung, P.; Menssen, A.; Mayr, D.; Hermeking, H. AP4 encodes a c-MYC-inducible repressor of p21. Proc. Natl. Acad. Sci. USA 2008, 105, 15046-15051. [CrossRef]

131. Hu, Y.F.; Luscher, B.; Admon, A.; Mermod, N.; Tjian, R. Transcription factor AP-4 contains multiple dimerization domains that regulate dimer specificity. Genes Dev. 1990, 4, 1741-1752. [CrossRef] [PubMed] 
132. Imai, K.; Okamoto, T. Transcriptional repression of human immunodeficiency virus type 1 by AP-4. J. Biol. Chem. 2006, 281, 12495-12505. [CrossRef]

133. Kim, M.Y.; Jeong, B.C.; Lee, J.H.; Kee, H.J.; Kook, H.; Kim, N.S.; Kim, Y.H.; Kim, J.K.; Ahn, K.Y.; Kim, K.K. A repressor complex, AP4 transcription factor and geminin, negatively regulates expression of target genes in nonneuronal cells. Proc. Natl. Acad. Sci. USA 2006, 103, 13074-13079. [CrossRef] [PubMed]

134. Jung, P.; Hermeking, H. The c-MYC-AP4-p21 cascade. Cell Cycle 2009, 8, 982-989. [CrossRef] [PubMed]

135. Ou, S.H.; Garcia-Martinez, L.F.; Paulssen, E.J.; Gaynor, R.B. Role of flanking E box motifs in human immunodeficiency virus type 1 TATA element function. J. Virol. 1994, 68, 7188-7199. [PubMed]

136. Ivanovska, I.; Ball, A.S.; Diaz, R.L.; Magnus, J.F.; Kibukawa, M.; Schelter, J.M.; Kobayashi, S.V.; Lim, L.; Burchard, J.; Jackson, A.L.; et al. MicroRNAs in the miR-106b family regulate p21/CDKN1A and promote cell cycle progression. Mol. Cell. Biol. 2008, 28, 2167-2174. [CrossRef] [PubMed]

137. Kim, Y.K.; Yu, J.; Han, T.S.; Park, S.Y.; Namkoong, B.; Kim, D.H.; Hur, K.; Yoo, M.W.; Lee, H.J.; Yang, H.K.; et al. Functional links between clustered microRNAs: Suppression of cell-cycle inhibitors by microRNA clusters in gastric cancer. Nucleic Acids Res. 2009, 37, 1672-1681. [CrossRef] [PubMed]

138. Petrocca, F.; Visone, R.; Onelli, M.R.; Shah, M.H.; Nicoloso, M.S.; de Martino, I.; Iliopoulos, D.; Pilozzi, E.; Liu, C.G.; Negrini, M.; et al. E2F1-regulated microRNAs impair TGF $\beta$-dependent cell-cycle arrest and apoptosis in gastric cancer. Cancer Cell 2008, 13, 272-286. [CrossRef]

139. Diosdado, B.; van de Wiel, M.A.; Terhaar Sive Droste, J.S.; Mongera, S.; Postma, C.; Meijerink, W.J.; Carvalho, B.; Meijer, G.A. MiR-17-92 cluster is associated with 13q gain and c-myc expression during colorectal adenoma to adenocarcinoma progression. Br. J. Cancer 2009, 101, 707-714. [CrossRef]

140. O’Donnell, K.A.; Wentzel, E.A.; Zeller, K.I.; Dang, C.V.; Mendell, J.T. c-Myc-regulated microRNAs modulate E2F1 expression. Nature 2005, 435, 839-843. [CrossRef]

141. Tagawa, H.; Karube, K.; Tsuzuki, S.; Ohshima, K.; Seto, M. Synergistic action of the microRNA-17 polycistron and Myc in aggressive cancer development. Cancer Sci. 2007, 98, 1482-1490. [CrossRef] [PubMed]

142. Wang, Z.; Liu, M.; Zhu, H.; Zhang, W.; He, S.; Hu, C.; Quan, L.; Bai, J.; Xu, N. Suppression of p21 by c-Myc through members of miR-17 family at the post-transcriptional level. Int. J. Oncol. 2010, 37, 1315-1321.

143. Bachs, O.; Gallastegui, E.; Orlando, S.; Bigas, A.; Morante-Redolat, J.M.; Serratosa, J.; Farinas, I.; Aligue, R.; Pujol, M.J. Role of $\mathrm{p} 27^{\mathrm{Kip} 1}$ as a transcriptional regulator. Oncotarget 2018, 9, 26259-26278. [CrossRef] [PubMed]

144. Mateyak, M.K.; Obaya, A.J.; Sedivy, J.M. c-Myc regulates cyclin D-Cdk4 and -Cdk6 activity but affects cell cycle progression at multiple independent points. Mol. Cell. Biol. 1999, 19, 4672-4683. [CrossRef]

145. Lutz, W.; Leon, J.; Eilers, M. Contributions of Myc to tumorigenesis. Biochim. Biophys. Acta 2002, 1602, 61-71. [CrossRef]

146. Martins, C.P.; Berns, A. Loss of $\mathrm{p} 27^{\mathrm{Kip} 1}$ but not $\mathrm{p} 21^{\mathrm{Cip} 1}$ decreases survival and synergizes with MYC in murine lymphomagenesis. EMBO J. 2002, 21, 3739-3748. [CrossRef]

147. Hnit, S.S.; Xie, C.; Yao, M.; Holst, J.; Bensoussan, A.; De Souza, P.; Li, Z.; Dong, Q. p27Kip1 signaling: Transcriptional and post-translational regulation. Int. J. Biochem. Cell Biol. 2015, 68, 9-14. [CrossRef]

148. Wu, M.; Bellas, R.E.; Shen, J.; Yang, W.; Sonenshein, G.E. Increased p27 ${ }^{\text {Kip1 }}$ cyclin-dependent kinase inhibitor gene expression following anti-IgM treatment promotes apoptosis of WEHI 231 B cells. J. Immunol. 1999, 163, 6530-6535. [PubMed]

149. Wu, M.; Arsura, M.; Bellas, R.E.; FitzGerald, M.J.; Lee, H.; Schauer, S.L.; Sherr, D.H.; Sonenshein, G.E. Inhibition of c-myc expression induces apoptosis of WEHI 231 murine B cells. Mol. Cell. Biol. 1996, 16, 5015-5025. [CrossRef] [PubMed]

150. Schauer, S.L.; Wang, Z.; Sonenshein, G.E.; Rothstein, T.L. Maintenance of nuclear factor-k $\beta /$ Rel and c-myc expression during CD40 ligand rescue of WEHI 231 early B cells from receptor-mediated apoptosis through modulation of I kappa B proteins. J. Immunol. 1996, 157, 81-86.

151. Yang, W.; Shen, J.; Wu, M.; Arsura, M.; FitzGerald, M.; Suldan, Z.; Kim, D.W.; Hofmann, C.S.; Pianetti, S.; Romieu-Mourez, R.; et al. Repression of transcription of the $\mathrm{p} 27^{\mathrm{Kip} 1}$ cyclin-dependent kinase inhibitor gene by c-Myc. Oncogene 2001, 20, 1688-1702. [CrossRef]

152. Lee, L.A.; Dolde, C.; Barrett, J.; Wu, C.S.; Dang, C.V. A link between c-Myc-mediated transcriptional repression and neoplastic transformation. J. Clin. Investig. 1996, 97, 1687-1695. [CrossRef]

153. Li, L.H.; Nerlov, C.; Prendergast, G.; MacGregor, D.; Ziff, E.B. c-Myc represses transcription in vivo by a novel mechanism dependent on the initiator element and Myc box II. EMBO J. 1994, 13, 4070-4079. [CrossRef] 
154. Chandramohan, V.; Mineva, N.D.; Burke, B.; Jeay, S.; Wu, M.; Shen, J.; Yang, W.; Hann, S.R.; Sonenshein, G.E. $\mathrm{c}-\mathrm{Myc}$ represses FOXO3a-mediated transcription of the gene encoding the $\mathrm{p} 27^{\mathrm{Kip} 1}$ cyclin dependent kinase inhibitor. J. Cell. Biochem. 2008, 104, 2091-2106. [CrossRef] [PubMed]

155. Chandramohan, V.; Jeay, S.; Pianetti, S.; Sonenshein, G.E. Reciprocal control of Forkhead box O 3a and c-Myc via the phosphatidylinositol 3-kinase pathway coordinately regulates p27 Kip1 levels. J. Immunol. 2004, 172, 5522-5527. [CrossRef]

156. Giglio, S.; Cirombella, R.; Amodeo, R.; Portaro, L.; Lavra, L.; Vecchione, A. MicroRNA miR-24 promotes cell proliferation by targeting the CDKs inhibitors $2^{\mathrm{K} i p 1}$ and p16 ${ }^{\mathrm{INK} 4 \mathrm{a}}$. J. Cell. Physiol. 2013, 228, 2015-2023. [CrossRef] [PubMed]

157. Gillies, J.K.; Lorimer, I.A. Regulation of $2^{27^{K i p} 1}$ by miRNA 221/222 in glioblastoma. Cell Cycle 2007, 6, 2005-2009. [CrossRef] [PubMed]

158. Lynch, S.M.; McKenna, M.M.; Walsh, C.P.; McKenna, D.J. miR-24 regulates CDKN1B/p27 expression in prostate cancer. Prostate 2016, 76, 637-648. [CrossRef] [PubMed]

159. Le Sage, C.; Nagel, R.; Egan, D.A.; Schrier, M.; Mesman, E.; Mangiola, A.; Anile, C.; Maira, G.; Mercatelli, N.; Ciafre, S.A.; et al. Regulation of the p27 ${ }^{\mathrm{Kip} 1}$ tumor suppressor by miR-221 and miR-222 promotes cancer cell proliferation. EMBO J. 2007, 26, 3699-3708. [CrossRef] [PubMed]

160. Kim, J.W.; Mori, S.; Nevins, J.R. Myc-induced microRNAs integrate Myc-mediated cell proliferation and cell fate. Cancer Res. 2010, 70, 4820-4828. [CrossRef]

161. Pineau, P.; Volinia, S.; McJunkin, K.; Marchio, A.; Battiston, C.; Terris, B.; Mazzaferro, V.; Lowe, S.W.; Croce, C.M.; Dejean, A. miR-221 overexpression contributes to liver tumorigenesis. Proc. Natl. Acad. Sci. USA 2010, 107, 264-269. [CrossRef]

162. Koff, A. How to decrease p27 ${ }^{\mathrm{Kip} 1}$ levels during tumor development. Cancer Cell 2006, 9, 75-76. [CrossRef]

163. James, M.K.; Ray, A.; Leznova, D.; Blain, S.W. Differential modification of p27Kip1 controls its cyclin D-cdk4 inhibitory activity. Mol. Cell. Biol. 2008, 28, 498-510. [CrossRef] [PubMed]

164. Ray, A.; James, M.K.; Larochelle, S.; Fisher, R.P.; Blain, S.W. p27Kip1 inhibits cyclin D-cyclin-dependent kinase 4 by two independent modes. Mol. Cell. Biol. 2009, 29, 986-999. [CrossRef] [PubMed]

165. Daksis, J.I.; Lu, R.Y.; Facchini, L.M.; Marhin, W.W.; Penn, L.J. Myc induces cyclin D1 expression in the absence of de novo protein synthesis and links mitogen-stimulated signal transduction to the cell cycle. Oncogene 1994, 9, 3635-3645. [PubMed]

166. Philipp, A.; Schneider, A.; Vasrik, I.; Finke, K.; Xiong, Y.; Beach, D.; Alitalo, K.; Eilers, M. Repression of cyclin D1: A novel function of MYC. Mol. Cell. Biol. 1994, 14, 4032-4043. [CrossRef] [PubMed]

167. Solomon, D.L.; Philipp, A.; Land, H.; Eilers, M. Expression of cyclin D1 mRNA is not upregulated by Myc in rat fibroblasts. Oncogene 1995, 11, 1893-1897.

168. Yu, Q.; Ciemerych, M.A.; Sicinski, P. Ras and Myc can drive oncogenic cell proliferation through individual D-cyclins. Oncogene 2005, 24, 7114-7119. [CrossRef] [PubMed]

169. Bouchard, C.; Dittrich, O.; Kiermaier, A.; Dohmann, K.; Menkel, A.; Eilers, M.; Luscher, B. Regulation of cyclin D2 gene expression by the Myc/Max/Mad network: Myc-dependent TRRAP recruitment and histone acetylation at the cyclin D2 promoter. Genes Dev. 2001, 15, 2042-2047. [CrossRef] [PubMed]

170. Bouchard, C.; Thieke, K.; Maier, A.; Saffrich, R.; Hanley-Hyde, J.; Ansorge, W.; Reed, S.; Sicinski, P.; Bartek, J.; Eilers, M. Direct induction of cyclin D2 by Myc contributes to cell cycle progression and sequestration of p27. EMBO J. 1999, 18, 5321-5333. [CrossRef]

171. Hermeking, H.; Rago, C.; Schuhmacher, M.; Li, Q.; Barrett, J.F.; Obaya, A.J.; O'Connell, B.C.; Mateyak, M.K.; Tam, W.; Kohlhuber, F.; et al. Identification of CDK4 as a target of c-MYC. Proc. Natl. Acad. Sci. USA 2000, 97, 2229-2234. [CrossRef] [PubMed]

172. Li, Z.; Van Calcar, S.; Qu, C.; Cavenee, W.K.; Zhang, M.Q.; Ren, B. A global transcriptional regulatory role for c-Myc in Burkitt's lymphoma cells. Proc. Natl. Acad. Sci. USA 2003, 100, 8164-8169. [CrossRef] [PubMed]

173. Yap, C.S.; Peterson, A.L.; Castellani, G.; Sedivy, J.M.; Neretti, N. Kinetic profiling of the c-Myc transcriptome and bioinformatic analysis of repressed gene promoters. Cell Cycle 2011, 10, 2184-2196. [CrossRef] [PubMed]

174. Kossatz, U.; Dietrich, N.; Zender, L.; Buer, J.; Manns, M.P.; Malek, N.P. Skp2-dependent degradation of p27 ${ }^{\mathrm{kip} 1}$ is essential for cell cycle progression. Genes Dev. 2004, 18, 2602-2607. [CrossRef] [PubMed]

175. Nakayama, K.; Nagahama, H.; Minamishima, Y.A.; Miyake, S.; Ishida, N.; Hatakeyama, S.; Kitagawa, M.; Iemura, S.; Natsume, T.; Nakayama, K.I. Skp2-mediated degradation of p27 regulates progression into mitosis. Dev. Cell 2004, 6, 661-672. [CrossRef] 
176. Tsvetkov, L.M.; Yeh, K.H.; Lee, S.J.; Sun, H.; Zhang, H. p27Kip1 ubiquitination and degradation is regulated by the SCF(Skp2) complex through phosphorylated Thr187 in p27. Curr. Biol. 1999, 9, 661-664. [CrossRef]

177. Kitagawa, K.; Kitagawa, M. The SCF-type E3 Ubiquitin Ligases as Cancer Targets. Curr. Cancer Drug Targets 2016, 16, 119-129. [CrossRef]

178. Nakayama, K.I.; Nakayama, K. Regulation of the cell cycle by SCF-type ubiquitin ligases. Semin. Cell Dev. Biol. 2005, 16, 323-333. [CrossRef]

179. Bretones, G.; Acosta, J.C.; Caraballo, J.M.; Ferrándiz, N.; Gómez-Casares, M.T.; Albajar, M.; Blanco, R.; Ruiz, P.; Hung, W.C.; Albero, M.P.; et al. SKP2 oncogene is a direct MYC target gene and MYC down-regulates p27 ${ }^{\mathrm{KIP} 1}$ through SKP2 in human leukemia cells. J. Biol. Chem. 2011, 286, 9815-9825. [CrossRef]

180. Muller, D.; Bouchard, C.; Rudolph, B.; Steiner, P.; Stuckmann, I.; Saffrich, R.; Ansorge, W.; Huttner, W.; Eilers, M. Cdk2-dependent phosphorylation of p27 facilitates its Myc-induced release from cyclin E/cdk2 complexes. Oncogene 1997, 15, 2561-2576. [CrossRef]

181. Montagnoli, A.; Fiore, F.; Eytan, E.; Carrano, A.C.; Draetta, G.F.; Hershko, A.; Pagano, M. Ubiquitination of p27 is regulated by Cdk-dependent phosphorylation and trimeric complex formation. Genes Dev. 1999, 13, 1181-1189. [CrossRef] [PubMed]

182. Berthet, C.; Aleem, E.; Coppola, V.; Tessarollo, L.; Kaldis, P. Cdk2 knockout mice are viable. Curr. Biol. 2003, 13, 1775-1785. [CrossRef]

183. Garcia-Gutierrez, L.; Bretones, G.; Leon, J. MYC stimulates cell-cycle progression through the activation of CDK1 and phosphorylation of p27. (manuscript in preparation).

184. Steiner, P.; Philipp, A.; Lukas, J.; Godden-Kent, D.; Pagano, M.; Mittnacht, S.; Bartek, J.; Eilers, M. Identification of a Myc-dependent step during the formation of active G1 cyclin-cdk complexes. EMBO J. 1995, 14, 4814-4826. [CrossRef] [PubMed]

185. Berns, K.; Hijmans, E.M.; Bernards, R. Repression of c-Myc responsive genes in cycling cells causes G1 arrest through reduction of cyclin E/CDK2 kinase activity. Oncogene 1997, 15, 1347-1356. [CrossRef]

186. Ohtani, K.; DeGregori, J.; Nevins, J.R. Regulation of the cyclin E gene by transcription factor E2F1. Proc. Natl. Acad. Sci. USA 1995, 92, 12146-12150. [CrossRef] [PubMed]

187. Ohtsubo, M.; Theodoras, A.M.; Schumacher, J.; Roberts, J.M.; Pagano, M. Human cyclin E, a nuclear protein essential for the $\mathrm{G}_{1}$-to-S phase transition. Mol. Cell. Biol. 1995, 15, 2612-2624. [CrossRef] [PubMed]

188. Mitxelena, J.; Apraiz, A.; Vallejo-Rodriguez, J.; Malumbres, M.; Zubiaga, A.M. E2F7 regulates transcription and maturation of multiple microRNAs to restrain cell proliferation. Nucleic Acids Res. 2016. [CrossRef]

189. Lolli, G.; Johnson, L.N. CAK-Cyclin-dependent Activating Kinase: A key kinase in cell cycle control and a target for drugs? Cell Cycle 2005, 4, 572-577. [CrossRef]

190. Morgan, D.O. Principles of CDK regulation. Nature 1995, 374, 131-134. [CrossRef]

191. Morgan, D.O. Cyclin-dependent kinases: Engines, clocks, and microprocessors. Annu. Rev. Cell Dev. Biol. 1997, 13, 261-291. [CrossRef] [PubMed]

192. Cowling, V.H.; Cole, M.D. The Myc transactivation domain promotes global phosphorylation of the RNA polymerase II carboxy-terminal domain independently of direct DNA binding. Mol. Cell. Biol. 2007, 27, 2059-2073. [CrossRef] [PubMed]

193. Obaya, A.J.; Kotenko, I.; Cole, M.D.; Sedivy, J.M. The proto-oncogene c-myc acts through the cyclindependent kinase (Cdk) inhibitor $\mathrm{p}^{27^{\mathrm{Kip}} 1}$ to facilitate the activation of $\mathrm{Cdk} 4 / 6$ and early $\mathrm{G}_{1}$ phase progression. J. Biol. Chem. 2002, 277, 31263-31269. [CrossRef] [PubMed]

194. Perez-Roger, I.; Solomon, D.L.; Sewing, A.; Land, H. Myc activation of cyclin E/Cdk2 kinase involves induction of cyclin E gene transcription and inhibition of $\mathrm{p} 27^{\mathrm{Kip} 1}$ binding to newly formed complexes. Oncogene 1997, 14, 2373-2381. [CrossRef]

195. Vlach, J.; Hennecke, S.; Amati, B. Phosphorylation-dependent degradation of the cyclin-dependent kinase inhibitor p27. EMBO J. 1997, 16, 5334-5344. [CrossRef]

196. Carrano, A.C.; Eytan, E.; Hershko, A.; Pagano, M. SKP2 is required for ubiquitin-mediated degradation of the CDK inhibitor p27. Nat. Cell Biol. 1999, 1, 193-199. [CrossRef] [PubMed]

197. Sutterluty, H.; Chatelain, E.; Marti, A.; Wirbelauer, C.; Senften, M.; Muller, U.; Krek, W. p45SKP2 promotes p27 Kip1 degradation and induces $S$ phase in quiescent cells. Nat. Cell Biol. 1999, 1, 207-214. [CrossRef]

198. Hao, B.; Zheng, N.; Schulman, B.A.; Wu, G.; Miller, J.J.; Pagano, M.; Pavletich, N.P. Structural basis of the Cks1-dependent recognition of p27 $^{\text {Kip1 }}$ by the SCF(Skp2) ubiquitin ligase. Mol. Cell 2005, 20, 9-19. [CrossRef] [PubMed] 
199. Nguyen, H.; Gitig, D.M.; Koff, A. Cell-free degradation of p27kip1 a $\mathrm{G}_{1}$ cyclin-dependent kinase inhibitor, is dependent on CDK2 activity and the proteasome. Mol. Cell. Biol. 1999, 19, 1190-1201. [CrossRef] [PubMed]

200. Zhu, X.H.; Nguyen, H.; Halicka, H.D.; Traganos, F.; Koff, A. Noncatalytic requirement for cyclin A-cdk2 in p27 turnover. Mol. Cell. Biol. 2004, 24, 6058-6066. [CrossRef] [PubMed]

201. Bourne, Y.; Watson, M.H.; Hickey, M.J.; Holmes, W.; Rocque, W.; Reed, S.I.; Tainer, J.A. Crystal structure and mutational analysis of the human CDK2 kinase complex with cell cycle-regulatory protein CksHs1. Cell 1996, 84, 863-874. [CrossRef]

202. Sitry, D.; Seeliger, M.A.; Ko, T.K.; Ganoth, D.; Breward, S.E.; Itzhaki, L.S.; Pagano, M.; Hershko, A. Three different binding sites of Cks1 are required for p27-ubiquitin ligation. J. Biol. Chem. 2002, 277, 42233-42240. [CrossRef] [PubMed]

203. Keller, U.B.; Old, J.B.; Dorsey, F.C.; Nilsson, J.A.; Nilsson, L.; MacLean, K.H.; Chung, L.; Yang, C.; Spruck, C.; Boyd, K.; et al. Myc targets Cks1 to provoke the suppression of $\mathrm{p} 27^{\mathrm{Kip} 1}$, proliferation and lymphomagenesis. EMBO J. 2007, 26, 2562-2574. [CrossRef]

204. O'Hagan, R.C.; Ohh, M.; David, G.; de Alboran, I.M.; Alt, F.W.; Kaelin, W.G., Jr.; DePinho, R.A. Myc-enhanced expression of Cul1 promotes ubiquitin-dependent proteolysis and cell cycle progression. Genes Dev. 2000, 14, 2185-2191. [CrossRef] [PubMed]

205. Skorski, T.; Nieborowska-Skorska, M.; Campbell, K.; Iozzo, R.V.; Zon, G.; Darzynkiewicz, Z.; Calabretta, B. Leukemia treatment in severe combined immunodeficiency mice by antisense oligodeoxynucleotides targeting cooperating oncogenes. J. Exp. Med. 1995, 182, 1645-1653. [CrossRef]

206. Skorski, T.; Nieborowska-Skorska, M.; Wlodarski, P.; Zon, G.; Iozzo, R.V.; Calabretta, B. Antisense oligodeoxynucleotide combination therapy of primary chronic myelogenous leukemia blast crisis in SCID mice. Blood 1996, 88, 1005-1012. [PubMed]

207. Roderick, J.E.; Tesell, J.; Shultz, L.D.; Brehm, M.A.; Greiner, D.L.; Harris, M.H.; Silverman, L.B.; Sallan, S.E.; Gutierrez, A.; Look, A.T.; et al. c-Myc inhibition prevents leukemia initiation in mice and impairs the growth of relapsed and induction failure pediatric T-ALL cells. Blood 2014, 123, 1040-1050. [CrossRef] [PubMed]

208. Weinstein, I.B. Cancer. Addiction to oncogenes-The Achilles heal of cancer. Science 2002, 297, 63-64. [CrossRef] [PubMed]

209. Soucek, L.; Helmer-Citterich, M.; Sacco, A.; Jucker, R.; Cesareni, G.; Nasi, S. Design and properties of a Myc derivative that efficiently homodimerizes. Oncogene 1998, 17, 2463-2472. [CrossRef] [PubMed]

210. Soucek, L.; Whitfield, J.R.; Sodir, N.M.; Masso-Valles, D.; Serrano, E.; Karnezis, A.N.; Swigart, L.B.; Evan, G.I. Inhibition of Myc family proteins eradicates KRas-driven lung cancer in mice. Genes Dev. 2013, 27, 504-513. [CrossRef]

211. Annibali, D.; Whitfield, J.R.; Favuzzi, E.; Jauset, T.; Serrano, E.; Cuartas, I.; Redondo-Campos, S.; Folch, G.; Gonzalez-Junca, A.; Sodir, N.M.; et al. Myc inhibition is effective against glioma and reveals a role for Myc in proficient mitosis. Nat. Commun. 2014, 5, 4632. [CrossRef]

212. Delmore, J.E.; Issa, G.C.; Lemieux, M.E.; Rahl, P.B.; Shi, J.; Jacobs, H.M.; Kastritis, E.; Gilpatrick, T.; Paranal, R.M.; Qi, J.; et al. BET bromodomain inhibition as a therapeutic strategy to target c-Myc. Cell 2011, 146, 904-917. [CrossRef] [PubMed]

213. Fowler, T.; Ghatak, P.; Price, D.H.; Conaway, R.; Conaway, J.; Chiang, C.M.; Bradner, J.E.; Shilatifard, A.; Roy, A.L. Regulation of MYC expression and differential JQ1 sensitivity in cancer cells. PLoS ONE 2014, 9, e87003. [CrossRef] [PubMed]

214. Bhadury, J.; Nilsson, L.M.; Muralidharan, S.V.; Green, L.C.; Li, Z.; Gesner, E.M.; Hansen, H.C.; Keller, U.B.; McLure, K.G.; Nilsson, J.A. BET and HDAC inhibitors induce similar genes and biological effects and synergize to kill in Myc-induced murine lymphoma. Proc. Natl. Acad. Sci. USA 2014, 111, E2721-E2730. [CrossRef] [PubMed]

215. Fletcher, S.; Prochownik, E.V. Small-molecule inhibitors of the Myc oncoprotein. Biochim. Biophys. Acta 2015, 1849, 525-543. [CrossRef]

216. Yin, X.; Giap, C.; Lazo, J.S.; Prochownik, E.V. Low molecular weight inhibitors of Myc-Max interaction and function. Oncogene 2003, 22, 6151-6159. [CrossRef] [PubMed]

217. Guo, J.; Parise, R.A.; Joseph, E.; Egorin, M.J.; Lazo, J.S.; Prochownik, E.V.; Eiseman, J.L. Efficacy, pharmacokinetics, tisssue distribution, and metabolism of the Myc-Max disruptor, 10058-F4 [Z,E]-5-[4-ethylbenzylidine]-2-thioxothiazolidin-4-one, in mice. Cancer Chemother. Pharmacol. 2009, 63, 615-625. [CrossRef] [PubMed] 
218. Toyoshima, M.; Howie, H.L.; Imakura, M.; Walsh, R.M.; Annis, J.E.; Chang, A.N.; Frazier, J.; Chau, B.N.; Loboda, A.; Linsley, P.S.; et al. Functional genomics identifies therapeutic targets for MYC-driven cancer. Proc. Natl. Acad. Sci. USA 2012, 109, 9545-9550. [CrossRef] [PubMed]

219. Cermelli, S.; Jang, I.S.; Bernard, B.; Grandori, C. Synthetic lethal screens as a means to understand and treat MYC-driven cancers. Cold Spring Harbor Perspect. Med. 2014, 4, a014209. [CrossRef] [PubMed]

220. Itzhaki, J.E.; Gilbert, C.S.; Porter, A.C. Construction by gene targeting in human cells of a "conditional" CDC2 mutant that rereplicates its DNA. Nat. Genet. 1997, 15, 258-265. [CrossRef]

221. Santamaria, D.; Barriere, C.; Cerqueira, A.; Hunt, S.; Tardy, C.; Newton, K.; Caceres, J.F.; Dubus, P.; Malumbres, M.; Barbacid, M. Cdk1 is sufficient to drive the mammalian cell cycle. Nature 2007, 448, 811-815. [CrossRef]

222. Gray, N.; Detivaud, L.; Doerig, C.; Meijer, L. ATP-site directed inhibitors of cyclin-dependent kinases. Curr. Med. Chem. 1999, 6, 859-875.

223. Cicenas, J.; Kalyan, K.; Sorokinas, A.; Stankunas, E.; Levy, J.; Meskinyte, I.; Stankevicius, V.; Kaupinis, A.; Valius, M. Roscovitine in cancer and other diseases. Ann. Transl. Med. 2015, 3, 135. [PubMed]

224. Goga, A.; Yang, D.; Tward, A.D.; Morgan, D.O.; Bishop, J.M. Inhibition of CDK1 as a potential therapy for tumors over-expressing MYC. Nat. Med. 2007, 13, 820-827. [CrossRef] [PubMed]

225. Horiuchi, D.; Kusdra, L.; Huskey, N.E.; Chandriani, S.; Lenburg, M.E.; Gonzalez-Angulo, A.M.; Creasman, K.J.; Bazarov, A.V.; Smyth, J.W.; Davis, S.E.; et al. MYC pathway activation in triple-negative breast cancer is synthetic lethal with CDK inhibition. J. Exp. Med. 2012, 209, 679-696. [CrossRef] [PubMed]

226. Liao, H.; Ji, F.; Ying, S. CDK1: Beyond cell cycle regulation. Aging 2017, 9, 2465-2466. [CrossRef]

227. Wade, M.; Wahl, G.M. c-Myc, genome instability, and tumorigenesis: The devil is in the details. Curr. Top. Microbiol. Immunol. 2006, 302, 169-203. [PubMed]

228. Prochownik, E.V.; Li, Y. The ever expanding role for c-Myc in promoting genomic instability. Cell Cycle 2007, 6, 1024-1029. [CrossRef] [PubMed]

229. Karlsson, A.; Deb-Basu, D.; Cherry, A.; Turner, S.; Ford, J.; Felsher, D.W. Defective double-strand DNA break repair and chromosomal translocations by MYC overexpression. Proc. Natl. Acad. Sci. USA 2003, 100, 9974-9979. [CrossRef]

230. Li, Q.; Dang, C.V. c-Myc overexpression uncouples DNA replication from mitosis. Mol. Cell. Biol. 1999, 19, 5339-5351. [CrossRef]

231. Kuschak, T.I.; Kuschak, B.C.; Taylor, C.L.; Wright, J.A.; Wiener, F.; Mai, S. c-Myc initiates illegitimate replication of the ribonucleotide reductase R2 gene. Oncogene 2002, 21, 909-920. [CrossRef]

232. Sheen, J.H.; Dickson, R.B. Overexpression of c-Myc alters $\mathrm{G}_{1} / \mathrm{S}$ arrest following ionizing radiation. Mol. Cell. Biol. 2002, 22, 1819-1833. [CrossRef]

233. Dominguez-Sola, D.; Ying, C.Y.; Grandori, C.; Ruggiero, L.; Chen, B.; Li, M.; Galloway, D.A.; Gu, W.; Gautier, J.; Dalla-Favera, R. Non-transcriptional control of DNA replication by c-Myc. Nature 2007, 448, 445-451. [CrossRef] [PubMed]

234. Robinson, K.; Asawachaicharn, N.; Galloway, D.A.; Grandori, C. c-Myc accelerates S-Phase and requires WRN to avoid replication stress. PLoS ONE 2009, 4, e5951. [CrossRef]

235. Albajar, M.; Gomez-Casares, M.T.; Llorca, J.; Mauleon, I.; Vaque, J.P.; Acosta, J.C.; Bermudez, A.; Donato, N.; Delgado, M.D.; Leon, J. MYC in chronic myeloid leukemia: Induction of aberrant DNA synthesis and association with poor response to imatinib. Mol. Cancer Res. 2011, 9, 564-576. [CrossRef]

236. Willems, E.; Dedobbeleer, M.; Digregorio, M.; Lombard, A.; Lumapat, P.N.; Rogister, B. The functional diversity of Aurora kinases: A comprehensive review. Cell Div. 2018, 13, 7. [CrossRef] [PubMed]

237. Den Hollander, J.; Rimpi, S.; Doherty, J.R.; Rudelius, M.; Buck, A.; Hoellein, A.; Kremer, M.; Graf, N.; Scheerer, M.; Hall, M.A.; et al. Aurora kinases A and B are up-regulated by Myc and are essential for maintenance of the malignant state. Blood 2010, 116, 1498-1505. [CrossRef] [PubMed]

238. Harrington, E.A.; Bebbington, D.; Moore, J.; Rasmussen, R.K.; Ajose-Adeogun, A.O.; Nakayama, T.; Graham, J.A.; Demur, C.; Hercend, T.; Diu-Hercend, A.; et al. VX-680, a potent and selective small-molecule inhibitor of the Aurora kinases, suppresses tumor growth in vivo. Nat. Med. 2004, 10, 262-267. [CrossRef]

239. Yang, D.; Liu, H.; Goga, A.; Kim, S.; Yuneva, M.; Bishop, J.M. Therapeutic potential of a synthetic lethal interaction between the MYC proto-oncogene and inhibition of aurora-B kinase. Proc. Natl. Acad. Sci. USA 2010, 107, 13836-13841. [CrossRef] [PubMed] 
240. McNeely, S.; Beckmann, R.; Bence Lin, A.K. CHEK again: Revisiting the development of CHK1 inhibitors for cancer therapy. Pharmacol. Ther. 2014, 142, 1-10. [CrossRef]

241. Thompson, R.; Eastman, A. The cancer therapeutic potential of Chk1 inhibitors: How mechanistic studies impact on clinical trial design. Br. J. Clin. Pharmacol. 2013, 76, 358-369. [CrossRef]

242. Hoglund, A.; Nilsson, L.M.; Muralidharan, S.V.; Hasvold, L.A.; Merta, P.; Rudelius, M.; Nikolova, V.; Keller, U.; Nilsson, J.A. Therapeutic implications for the induced levels of Chk1 in Myc-expressing cancer cells. Clin. Cancer Res. 2011, 17, 7067-7079. [CrossRef] [PubMed]

243. Huang, C.H.; Lujambio, A.; Zuber, J.; Tschaharganeh, D.F.; Doran, M.G.; Evans, M.J.; Kitzing, T.; Zhu, N.; de Stanchina, E.; Sawyers, C.L.; et al. CDK9-mediated transcription elongation is required for MYC addiction in hepatocellular carcinoma. Genes Dev. 2014, 28, 1800-1814. [CrossRef] [PubMed]

(c) 2019 by the authors. Licensee MDPI, Basel, Switzerland. This article is an open access article distributed under the terms and conditions of the Creative Commons Attribution (CC BY) license (http:// creativecommons.org/licenses/by/4.0/). 